\title{
Influence of Fuel Injection, Turbocharging and EGR Systems Control on Combustion Parameters in an Automotive Diesel Engine
}

\author{
Giorgio Zamboni ${ }^{\mathbb{D}}$ \\ Internal Combustion Engines Group (ICEG)-Department of Mechanical, Energy, Management and \\ Transportation Engineering (DIME)-University of Genoa, via Montallegro 1, 16145 Genoa, Italy; \\ giorgio.zamboni@unige.it; Tel.: +39-010-33-52457
}

Received: 13 December 2018; Accepted: 28 January 2019; Published: 30 January 2019

Featured Application: The research presented in the paper is related to the development of a tool aiming at an extended analysis of combustion process based on an indicating technique and the evaluation of quantities summarizing trends of in-cylinder pressure diagrams and curves of heat release. This method can be applied to the comparison of different alternative fuels with conventional ones, integrating outcomes related to changes in fuel consumption and exhaust emissions.

\begin{abstract}
Indicated pressure diagrams were measured during experimental campaigns on the control of fuel injection, turbocharging and hybrid exhaust gas recirculation systems in an automotive downsized diesel engine. Three-part load operating conditions were selected for four test sets, where strategies aimed at the reduction of $\mathrm{NO}_{\mathrm{X}}$ emissions and fuel consumption, limiting penalties in soot emissions and combustion noise were applied to the selected systems. Processing of in-cylinder pressure signal, its first derivative and curves of the rate of heat release allowed us to evaluate seven parameters related to the combustion centre and duration, maximum values of pressure, heat release and its first derivative, heat released in the premixed phase and a combustion noise indicator. Relationships between these quantities and engine operating, energy and environmental parameters were then obtained by referring to the four test sets. In the paper, the most significant links are presented and discussed, aiming at a better understanding of the influence of control variables on the combustion process and the effects on engine behaviour. The proposed methodology proved to be a consistent tool for this analysis, useful for supporting the application of alternative fuels or advanced combustion modes.
\end{abstract}

Keywords: diesel engine; in-cylinder pressure diagrams; rate of heat release; combustion parameters; high and low-pressure EGR; variable geometry turbine control; rail pressure control; $\mathrm{NO}$ and soot emissions; fuel consumption

\section{Introduction}

Diesel engines are losing popularity, especially in the transport sector considering both private and public mobility, due to their negative impact on $\mathrm{NO}_{\mathrm{X}}$ and Particulate Matter (PM) emissions and the high costs required to develop propulsion systems complying with current and future legislation. Nevertheless, their complete replacement in all the applications is hard to be predicted, taking into account their overall efficiency and amount of energy which can be stored on a vehicle.

As a consequence, investigations on the main engine subsystems and their influence on performance, fuel consumption and emissions are still worth to be made, especially if focusing 
on peculiar aspects such as the combustion process and its relationship with operating, energy and environmental parameters.

Taking into account this point, the paper presents an experimental study on the analysis of changes in a wide set of combustion parameters when applying control strategies to fuel injection, turbocharging and hybrid exhaust gas recirculation (EGR) systems in an automotive diesel engine with a total displacement of $1.248 \mathrm{dm}^{3}$. Combustion parameters were obtained through proper processing of indicated pressure diagrams, the first derivative of the in-cylinder pressure signal and rate of heat release (RoHR) curves. Relationships between these parameters, fuel consumption and emissions were developed in order to describe the observed variations, offering numerical instruments for the modelling of detected trends and the development of suitable control strategies aiming at the achievement of proper goals involving selected variables.

Innovative aspects of the study are related to the definition of a database wider than what is commonly available and investigated, as few combustion parameters are usually calculated to allow a qualitative analysis while neglecting reciprocal interactions. On the other hand, the experimental campaigns involved three part-load working conditions and a large number of different operating modes resulting from a combination of selected control variables, focusing on a downsized engine.

While a previous paper [1] was focused on the influence of the EGR rate and variable nozzle turbine (VNT) control on engine quantities, pressure diagrams and combustion parameters, this paper refers to whole sets of experimental campaigns, thus including the effects of rail pressure management. A further goal was to identify similarities in the influence of the three sub-systems control on observed trends of measured parameters.

\subsection{Analysis of Indicated Pressure Diagrams in Recent Literature}

Referring to two engine subsystems controlled in the present study (fuel injection and EGR systems), the analysis of the available literature published in recent years confirms the above-mentioned fact, as indicated pressure diagrams and heat release curves are widely presented but their further processing is not generally applied. The investigations on alternative fuels can be supported by in-cylinder measurements, as discussed in Reference [2] considering the influence of diesel injection pressure and timing in a dual-fuel large displacement $(7.8 \mathrm{~L})$ turbocharged engine. A premixed mixture of methanol and air was ignited by the direct injection of diesel oil. The increase of diesel injection pressure led to rising levels of peak pressure, maximum heat release and combustion noise, reducing ignition delay and combustion duration. Similar effects were observed when advancing injection timing, except for ignition delay.

Natural gas was tested in Reference [3], where a single cylinder engine (2.0 L) derived from a heavy-duty diesel unit was modified to compare different mixture strategies (stoichiometric and lean conditions) and ignition modes (spark or diesel pilot). A mixture between natural gas and hydrogen was also considered. The rate of heat release was evaluated to assess the development of the combustion process for the different conditions at part and full load, referring to changes in ignition delay, combustion duration and maximum heat release.

Combustion control in a dual fuel engine was also investigated in Reference [4]. Two load levels were tested in a single cylinder engine $(0.51 \mathrm{~L})$, in order to optimize the amount of natural gas and diesel when comparing strategies for the management of indicated mean effective pressure (imep) and centre of combustion. Maximum pressure and rate of heat release were considered in order to assess the effectiveness of imep and $\theta_{50}$ control.

Biofuel obtained from canola oil was studied in Reference [5], where diesel oil, a B20 blend and neat canola oil were compared through measurements made in four different load levels at a constant speed on a $2.0 \mathrm{~L}$ common rail diesel engine. Lower values of maximum pressure and heat release were observed when using alternative fuel, while the oxygen content of canola oil led to a reduction of ignition delay. 
The effects of adding ethylene glycol in different proportion (from $5 \%$ to $15 \%$ ) to diesel oil were studied in Reference [6], considering a common rail diesel engine with a 7.8 L displacement. Tests were developed for six levels of engine load at the rotational speed corresponding to rated torque. The most significant variations were observed at intermediate and high load, where the addition of ethylene glycol led to an increase in the maximum pressure, the rate of heat release and pressure rise rate, reducing ignition delay and combustion duration.

The development of advanced combustion mode is also based on heat release analysis, as presented in Reference [7], where a reactivity controlled compression ignition engine was considered. In this case, an opposite influence of the increase of fuel pressure injection, compared to the expected behaviour, was observed, resulting in lower maximum values of heat release and peak pressure, longer ignition delay and combustion duration. These outcomes were the effects of the reduced spray penetration related to the lower average diameter of fuel droplets and the worst combustion propagation to gasoline.

In Reference [8], the rate of heat release was used in order to reduce fuel consumption and combustion noise when applying multiple fuel injection strategies to a single cylinder diesel engine, featuring pre-mixed combustion, with a displacement of $0.55 \mathrm{~L}$. The rate of heat release and combustion noise were modelled, in order to design the injection strategies when actuating from two to five events, sharing the amount of injected fuel among them in order to minimize noise while achieving the highest thermal efficiency.

Further examples of pressure diagrams analysis can be considered referring to the application of EGR technique. In Reference [9], heat release was observed when switching from the high-pressure (HP) circuit to the low-pressure (LP) or dual loops in a large (8.42 L) heavy-duty engine. Minor changes in ignition delay and the maximum value of RoHR were apparent, as a consequence of a strategy with only one injection, before top dead centre (TDC).

In Reference [10], internal and low-pressure recirculation were compared to the HP loop in a single cylinder diesel engine. Pressure and heat release curves allowed to evaluate the influence of intake valve closing strategies. With a proper selection of valve overlap, internal and low-pressure EGR, pumping losses and fuel consumption were decreased, without affecting heat release and emission levels observed with the application of standard high-pressure EGR circuit.

\subsection{Effects of Rail Pressure Control}

General studies describing the influence of rail pressure control on the development of spray in the combustion chamber should be also considered, in order to explain changes of different parameters observed in this investigation when managing this control variable. In Reference [11], spray tip penetration (i.e., the maximum distance of the injected spray from the injector nozzle tip measured on the axial direction) was evaluated when applying four values of injection pressure for two levels of cylinder pressure, using conventional diesel oil. Higher spray tip penetration was observed if injection pressure raised. Moreover, the higher momentum of small droplets resulted in the enlargement of the spray area. In reference [12], diesel spray was analysed in a constant volume combustion chamber, assessing that the increase of injection pressure resulted in a better atomisation of fuel droplets. As a consequence, evaporation and mixture formation were enhanced, leading to a shorter combustion duration.

Large variations of injection pressure were compared in Reference [13], where a turbocharged engine $\left(2.18 \mathrm{dm}^{3}\right)$ fuelled with a blend $80 \%$ diesel-20\% Karanja biodiesel was tested. A Delphi fuel injection system was considered, with six-holes solenoid injectors. Increasing fuel injection pressure from 500 to 1000 bar enhanced the spray evolution, with significant lower times to reach the same penetration length, while a similar behaviour of fuel jets was observed when comparing 1000 and 1500 bar of injection pressure, even if a slightly faster evolution was apparent with the highest pressure level.

The expected effects of these variations in spray development and mixture formation when applying increased levels of injection pressure to an engine are therefore a shorter ignition delay, 
a rise in peak pressure and maximum level of heat release and a reduced combustion duration. These results are widely reported in the literature, referring to studies on different engine types and fuels. Low displacement units fuelled with biofuels were tested in References [14,15], while four cylinders naturally aspirated engine was considered in Reference [16]. On the other side, a single cylinder engine with a large displacement $\left(8.8 \mathrm{dm}^{3}\right)$ was studied in Reference [17], applying a simple injection strategy based on one event while considering three different levels of in-cylinder gas density.

A further effect of higher pressure levels for fuel injection is related to a stronger premixed combustion phase, proved by a faster rise of pressure [18] and heat release [19]. In these cases, alternative fuels and very different engine sizes were considered (natural gas in an $11.6 \mathrm{dm}^{3}$ displacement unit [18] and a B20 biodiesel blend for a naturally aspirated single cylinder engine of $\left.0.51 \mathrm{dm}^{3}[19]\right)$.

As a further consequence of the achievement of a better combustion process, energy and environmental parameters are also modified, with lower levels of fuel consumption and soot emissions and the increase of $\mathrm{NO}_{\mathrm{X}}$ emissions. The first result is due to the shift of the combustion centre towards the TDC and to the shorter duration of combustion [14-18]. Soot reduction is related to the enhancement of the premixed phase of the combustion $[11,14,15,19]$. The faster combustion process, especially in the first phase, leads to an increase of maximum pressure and temperature levels, justifying the higher $\mathrm{NO}_{x}$ generation $[14-17,19]$.

As already stated, the goal of this study was to prove the capability of indicated pressure diagrams and related combustion parameters to enlarge the outcomes of measurements, extending the relevant knowledge on the influence of main engine subsystems control. The paper includes a Methodology Section, where the engine and its open control system are described, while control variables are defined. The acquisition system for pressure diagram measurements and processing procedure for RoHR calculation are presented. An overview of the selected combustion parameters with the relevant definitions is then introduced. The four phases of the investigation program are then summarised. Section 3 is related to the discussion of the most important outcomes, where correlations between engine quantities are shown and analysed.

\section{Methodologies}

\subsection{Engine Test Facility}

Table 1 presents the main technical specifications of tested diesel engine, a Direct Injection Euro 5 turbocharged unit for automotive application. Figure 1 shows a scheme of the engine, with the layout of high and low-pressure EGR circuits. Commercial diesel oil was used for all the tests, with the maximum content of renewables allowed by the European legislation (7\%), a cetane number of 52.1, a maximum Sulphur content of $10 \mathrm{ppm}$ and density at $20{ }^{\circ} \mathrm{C}$ of $836 \mathrm{~g} / \mathrm{dm}^{3}$. A stoichiometric air-fuel ratio was equal to 14.5 and lower heating value to $42.7 \mathrm{MJ} / \mathrm{kg}$.

Fitted on a steady state eddy current dynamometer test bench, the engine was instrumented for the acquisition of a wide set of quantities. Pressure and temperature were measured with strain gauge transducers, platinum resistance thermometers and K-type thermocouples in different sections of intake and exhaust circuits. Temperature control was applied to coolant, lubricant oil and intake charge to minimize the influence on engine behaviour and to achieve proper levels of intercooler efficiency, managing thermostatic circuits and water flow rate.

Air mass flow rate and engine rotational speed were measured by on-board engine sensors, while fuel consumption was directly obtained from an AVL 733S (AVL List, Graz, Austria) measuring equipment. Turbocharger rotational speed was acquired by an eddy current probe, installed close to the compressor rotor.

Exhaust gas analysers evaluated carbon dioxide and nitrogen oxide concentrations. A variable sampling smoke meter measured exhaust smoke, expressed in Filter Smoke Number (FSN), while soot concentration (expressed in $\mathrm{mg} / \mathrm{m}^{3}$ ) was calculated according to a correlation defined by the 
instrument manufacturer. The density of gases was evaluated measuring pressure and temperature in the sampling section of the smoke meter, thus allowing us to assess volumetric flow rate of exhaust gases, soot mass flow rate and the relevant specific emission (bsS).

Table 1. Characteristics of the tested engine.

\begin{tabular}{cc}
\hline Characteristics & Description/Value \\
\hline Engine type & Four-stroke, Diesel \\
\hline Cylinders & 4 in-line \\
\hline Bore $[\mathrm{mm}] \times$ stroke $[\mathrm{mm}]$ & $69.9 \times 82$ \\
\hline Total displacement $\left[\mathrm{cm}^{3}\right]$ & 1248 \\
\hline Compression ratio & $16.8: 1$ \\
\hline Valves for cylinder & 4 \\
\hline Intake Valve Opening & 12 CAD BTDC \\
\hline Intake Valve Closure & 12 CAD ABDC \\
\hline Exhaust Valve Opening & 24 CAD BBDC \\
\hline Exhaust Valve Closure & 70 at 4000 rpm \\
\hline Maximum Power $[\mathrm{kW}]$ & 200 at 1500-3000 rpm \\
\hline Maximum Torque $[\mathrm{Nm}]$ & Direct injection, Multijet II common rail with solenoid injectors, \\
\hline Fuel injection system & maximum pressure 1650 bar \\
\hline Turbocharging system & Single stage, variable nozzle turbine, intercooler \\
\hline HP EGR system & Standard HP circuit, cooled \\
\hline LP EGR system & Prototype LP loop, cooled \\
\hline
\end{tabular}

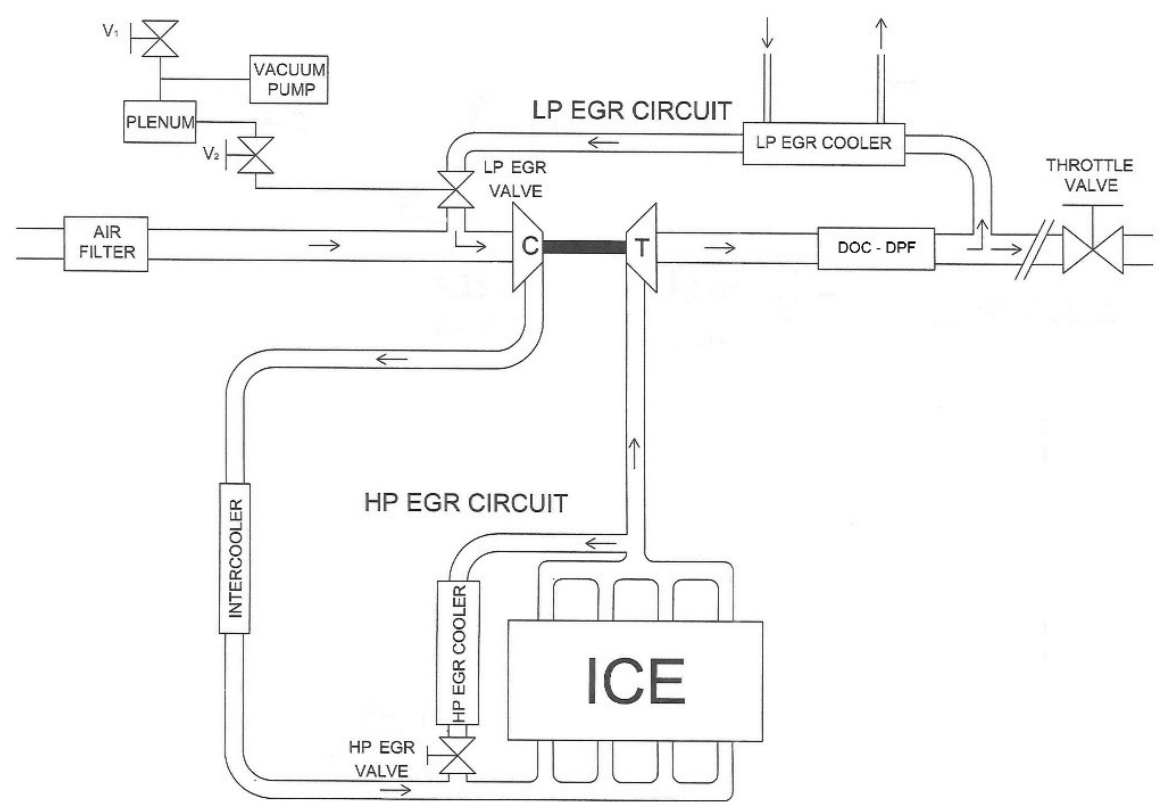

Figure 1. Scheme of the tested engine [1].

An automatic data acquisition system performed low-frequency measurements in steady-state conditions, using virtual instruments developed in Labview ${ }^{\circledR}$, while data processing was developed in Excel $^{\circledR}$, to calculate statistical parameters of observed quantities (average, standard deviation, variation 
coefficient) and the main engine parameters. Further details on experimental layout, instrument characteristics and uncertainties are presented in References [20,21].

\subsection{Engine Management System and Control Variables}

An open electronic control unit (ECU) fitted with an Erasable Programmable Read Only Memory (EPROM) emulator module was connected to a personal computer through an ETAS ${ }^{\circledR}$ MAC2F interface (ETAS, Stuttgart, Germany). The ETK module was then managed by the INCA ${ }^{\circledR}$ software, in order to perform real-time visualization of engine parameters, selection of the required maps stored in the ECU and change of control variables according to the experimental program.

Open and closed-loop strategies were available for turbocharger turbine control, according to the engine operating condition. The first option was applied by the ECU at low levels of engine speed and load, setting duty-cycle values of an electro-pneumatic valve $\left(\mathrm{DC}_{\mathrm{VNT}}\right)$, thus obtaining fixed values of variable nozzle turbine opening degree $\left(\mathrm{A}_{\mathrm{VNT}}\right)$, defined in Equation (1).

$$
\mathrm{A}_{\mathrm{VNT}}=\left[\left(\mathrm{S}_{\mathrm{MAX}}-\mathrm{S}\right) /\left(\mathrm{S}_{\mathrm{MAX}}-\mathrm{S}_{\mathrm{MIN}}\right] \times 100[\%] .\right.
$$

where $S$ is the displacement of the turbine nozzle ring push rod (measured with a linear potentiometer), while $S_{M A X}$ and $S_{\text {MIN }}$ are its maximum and minimum value. $A_{V N T}$ ranges from $0 \%$ to $100 \%$, equivalent to the minimum and maximum values of turbine swallowing area.

At higher levels of engine speed and load, ECU switched to the closed-loop control scheme, by comparing an intake pressure set point with the measured level, then changing $\mathrm{DC}_{\mathrm{VNT}}$ to reduce, if necessary, the calculated difference.

A closed-loop approach was applied to fuel rail pressure $\left(p_{\text {rail }}\right)$, through the comparison of the set point (calculated by the ECU according to the engine operating condition or fixed according to the experimental programme) and the level measured by the on board sensor fitted on the common rail.

The high-pressure (HP) EGR system was also controlled through a closed-loop scheme, based on the set point for the relative air-fuel ratio (AFR). The actual value was obtained by the measurement of the air mass flow rate, while fuel mass flow rate was calculated by the ECU to match the engine torque requested by the driver. The duty-cycle of the electric HP EGR valve ( $\mathrm{DC}_{\mathrm{EGR}}$ ) was then modulated to reduce the difference, thus managing its opening degree and HP EGR mass flow rate.

The prototype low-pressure (LP) EGR loop was manually controlled through two different devices. The first was a pneumatic valve, whose opening degree was managed through a vacuum signal. The second was a throttle valve (TV) fitted at the exhaust end [20], whose position allowed us to modify the pressure levels along this circuit (taking into account the absence of a diesel particulate filter) and low-pressure EGR contribution.

The conventional approach to define and calculate the EGR rate $\left(f_{\mathrm{EGR}}\right)$ was applied within the investigation. This term is defined as the ratio between recirculated gas and total engine mass flow rate, which is obtained summing air $\left(\mathrm{M}_{\mathrm{a}}\right)$, fuel $\left(\mathrm{M}_{\mathrm{f}}\right)$ and EGR $\left(\mathrm{M}_{\mathrm{EGR}}\right)$ mass flow rates (Equation (2)).

$$
\mathrm{f}_{\mathrm{EGR}}=\left[\mathrm{M}_{\mathrm{EGR}} /\left(\mathrm{M}_{\mathrm{EGR}}+\mathrm{M}_{\mathrm{a}}+\mathrm{M}_{\mathrm{f}}\right)\right] \times 100[\%]
$$

Measurements of ambient, intake and exhaust carbon dioxide concentrations through NDIR analysers, allowed to calculate the EGR rate $[22,23]$ according to Equation $(3)$ :

$$
\mathrm{f}_{\mathrm{EGR}}=\left[\left(\mathrm{X}_{\mathrm{CO} 2 \mathrm{i}}-\mathrm{X}_{\mathrm{CO} 2 \mathrm{a}}\right) /\left(\mathrm{X}_{\mathrm{CO} 2 \mathrm{e}}-\mathrm{X}_{\mathrm{CO} 2 \mathrm{a}}\right)\right] \times 100[\%] .
$$

As air and fuel mass flow rates were measured, Equation (2) allowed us to estimate $\mathrm{M}_{\mathrm{EGR}}$, corresponding to the mass flowing in one circuit when either HP or LP loop was activated or to the total mass of recirculated gases when both were jointly operated. In this case, the distribution between the two loops was assessed through a simplified energy balance based on the measured temperature levels in the intake and EGR circuits, neglecting heat losses and changes of constant 
pressure specific heat with temperature. Therefore, overall EGR mass flow rate was divided into two contributions (Equation (4)), where $\mathrm{M}_{\mathrm{HP}}$ EGR is recirculated by the high-pressure loop and $\mathrm{M}_{\mathrm{LP}}$ EGR by the low-pressure circuit.

$$
\mathrm{M}_{\mathrm{EGR}}=\mathrm{M}_{\mathrm{HP}} \mathrm{EGR}+\mathrm{M}_{\mathrm{LP} \text { EGR }} .
$$

Equation (5) identifies LP EGR loop contribution referred to the overall EGR mass flow rate, which allows us to weight the input from each circuit, depending on engine operating mode [21].

$$
\mathrm{LP}_{\text {proportion }}=\mathrm{M}_{\mathrm{LP} \text { EGR }} / \mathrm{M}_{\mathrm{EGR}}
$$

A non-dimensional EGR rate, namely the Charge Dilution Index (CDI), was also evaluated, in order to normalize the effects of engine load on EGR and to compare $f_{\mathrm{EGR}}$ in different working conditions. This parameter was calculated according to Equation (6) [24], where the oxygen concentration at the engine intake $\left(\mathrm{X}_{\mathrm{O} 2 \mathrm{i}}\right)$ accounts for the dilution effect, while the oxygen content in the exhaust/recirculated gases $\left(\mathrm{X}_{\mathrm{O} 2 \mathrm{e}}\right)$ depends on the engine load.

$$
\mathrm{CDI}=\mathrm{EGR} \text { level } / \text { Load level }=\left[\left(\mathrm{X}_{\mathrm{O} 2 \mathrm{a}}-\mathrm{X}_{\mathrm{O} 2 \mathrm{i}}\right) /\left(\mathrm{X}_{\mathrm{O} 2 \mathrm{i}}-\mathrm{X}_{\mathrm{O} 2 \mathrm{e}}\right)\right]
$$

Further details on this index and its calculation are presented in References [21,22,24].

\subsection{Measurement of in-Cylinder Pressure Diagrams and Calculation of Rate of Heat Release}

In-cylinder pressure diagrams were measured through a dedicated system, sampling four signals at a frequency rate selected according to the engine rotational speed in order to obtain a time period corresponding to a 0.1 crank angle rotation (i.e., $90 \mathrm{kHz}$ for $\mathrm{n}=1500 \mathrm{rpm}, 120 \mathrm{kHz}$ for $\mathrm{n}=2000 \mathrm{rpm}$ and $150 \mathrm{kHz}$ for $\mathrm{n}=2500 \mathrm{rpm}$ ). An uncooled piezoelectric transducer (Kistler 6125B, Kistler, Winterthur, Switzerland) was fitted in the glow plug seat of a cylinder for pressure measurements, while fuel pressure upstream of the injector and injector energising current of the same cylinder were also acquired, by means of a piezo-resistive transducer (Kistler 4067A2000, Kistler, Winterthur, Switzerland) and a current sensor, respectively. Crank angle was measured with a photoelectric incremental encoder.

The measuring chains were completed by signal amplifiers (Kiag Swiss 5001 and Kistler 4618A2, Kistler, Winterthur, Switzerland) and a high frequency sampling device (NI PCI-6123, National Instruments, Austin, TX, USA). Data were processed by dedicated virtual instruments developed in a LabVIEW ${ }^{\circledR}$ environment, to evaluate the absolute pressure levels, to filter in-cylinder pressure signal and to calculate the average pressure diagram, peak pressure and the relevant crank angle.

The calculation of the experimental rate of heat release for each tested engine operating condition was based on Equation (7):

$$
(\Delta \mathrm{Q} / \Delta \theta)=[\mathrm{k} /(\mathrm{k}-1)] \times \mathrm{p} \times(\Delta \mathrm{V} / \Delta \theta)+[1 /(\mathrm{k}-1)] \times(\Delta \mathrm{p} / \Delta \theta)+\left(\Delta \mathrm{Q}_{\text {coolant }} / \Delta \theta\right) .
$$

Equation (7) was implemented in a Fortran code developed by the author. $\Delta \mathrm{Q}$ is the heat released during a crankshaft rotation $\Delta \theta$. The application of the first thermodynamics law to the cylinder gas, assuming complete combustion and neglecting the variation of mass due to fuel injection $[25,26]$, allows us to identify the three terms of Equation (7). The first is related to the measured level of in-cylinder pressure, multiplied for the corresponding variation of instantaneous cylinder volume (computed from the measured crank angle and engine geometry characteristics). The second is related to the pressure gradient between two subsequent samples, while the third represents heat transferred to the coolant, estimated using the Hohenberg correlation [27].

The composition of intake charge and components inside the cylinder during combustion were considered for the evaluation of specific heats and their ratio, as well as their temperature, applying thermodynamic property functions of different gases listed in Reference [28].

The injected fuel mass flow rate in each calculation step was derived from experimental data of injected quantities. Actual values of the pilot, pre and main injections start and their duration were 
estimated by adding proper delays at the start and end of the current signal, according to Reference [29]. All the numerical values of the start of injections and timings presented in Tables 3-8 and Figures 2-6 were obtained through this approach.

\subsection{Evaluation of Combustion Parameters}

Figure 2 shows an example of in-cylinder pressure with the relevant first derivative $(\mathrm{dp} / \mathrm{d} \theta)$, which was calculated after proper filtering of the pressure signal. The actual timing of the three injections is also presented. Injection timings were kept constant at their standard levels in each operating point, as well as pilot and pre-injected quantities (Tables 3-5). As zero crank angle degree corresponded to the beginning of the intake stroke, combustion TDC occurred at 360 crank angle degrees. From the pressure trace, two maximum values are apparent, the first related to the compression stroke and to the combustion of pilot and pre-injections, the second to the main combustion. This behaviour, observed in all the tested conditions, is typical of automotive diesel engines since Euro 2/Euro 3 phases of the legislation on exhaust emissions, due to the shift of main injection timing towards or after the top dead centre in order to reduce $\mathrm{NO}_{\mathbf{X}}$. For the statistical analysis, the second maximum level was always considered.

Referring to the first derivative of pressure signal, both maximum values $(\mathrm{dp} / \mathrm{d} \theta)_{\operatorname{MAX} 1}$ and $(\mathrm{dp} / \mathrm{d} \theta)_{\operatorname{MAX} 2}$ were considered, together with a further level $(\mathrm{dp} / \mathrm{d} \theta)_{\mathrm{MAX}}$, derived from the pressure derivative of the compression-expansion signal in the unfired engine, at the same intake conditions.

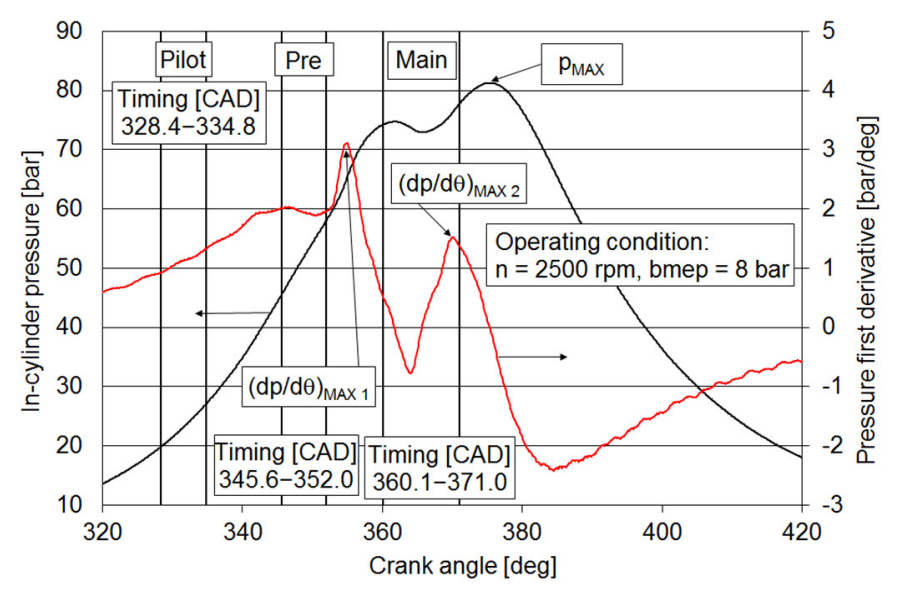

Figure 2. Example of an in-cylinder pressure diagram, the curve of the pressure first derivative and related parameters.

A combustion noise indicator $I_{n}$ was therefore evaluated, applying Equation (8) [30]:

$$
\mathrm{I}_{\mathrm{n}}=\mathrm{n} / \mathrm{n}_{\text {idle }} \times\left[(\mathrm{dp} / \mathrm{d} \theta)_{\operatorname{MAX} 1}+(\mathrm{dp} / \mathrm{d} \theta)_{\operatorname{MAX} 2}\right] /(\mathrm{dp} / \mathrm{d} \theta)_{\operatorname{MAX}}
$$

where $n$ is the engine speed of the tested condition and $n_{\text {idle }}$ is the engine speed in the idling mode.

Figure 3 presents an example of the rate of heat release with two relevant parameters obtained from this curve, i.e., the maximum value of heat flux ( RoHR $_{M A X}$ ) and the heat released during the premixed phase of the main combustion $\left(\mathrm{HR}_{\text {premix }}\right)$. The second quantity was estimated following the procedure shown in Reference [31], calculating the heat released from the start of the main combustion (corresponding to the lowest level of heat release following the combustion of the pilot and pre-injections) till to the crank angle at which RoHR $\mathrm{MAX}_{\mathrm{X}}$ occurred. Always referring to the premixed phase of the main combustion, another parameter was obtained, through the calculation of the first derivative of the rate of heat release and the evaluation of the relevant maximum value $(\mathrm{dRoHR} / \mathrm{d} \theta)_{\mathrm{MAx}}$. This quantity allowed us to further assess how the combustion process developed in the first period, following the ignition of the fuel injected during the main event. 


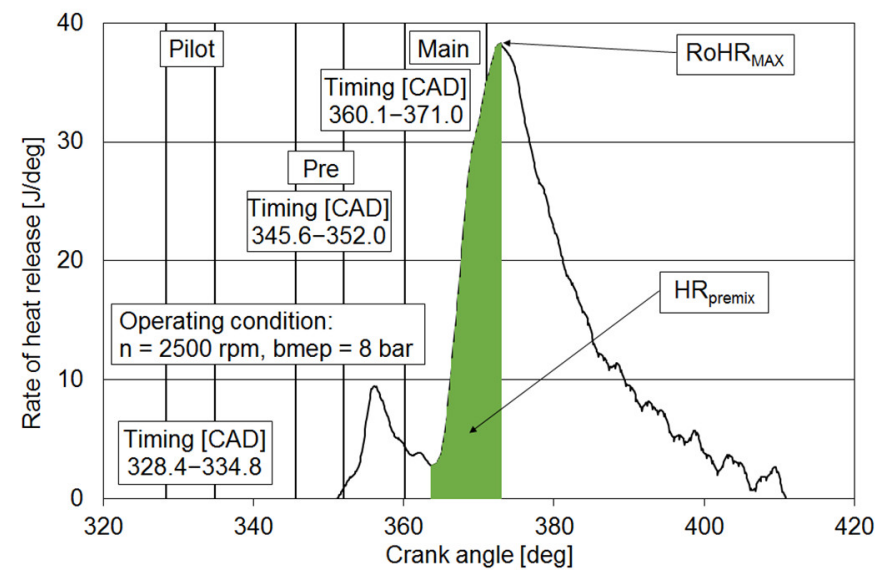

Figure 3. Example of the rate of heat release curve and related combustion parameters.

Figure 4 shows the mass fraction burned, obtained by the integration of heat release rate, and the crank angles corresponding to the release of $10 \%, 50 \%$ and $90 \%$ of the total heat. $\theta_{50}$ represents the centre of combustion and is useful for its control [32]. The difference $\left(\theta_{90}-\theta_{10}\right)$ is commonly assumed as an index of combustion duration, as the initial and final phases may be affected by significant uncertainties in the estimation of actual burning start and end angles.

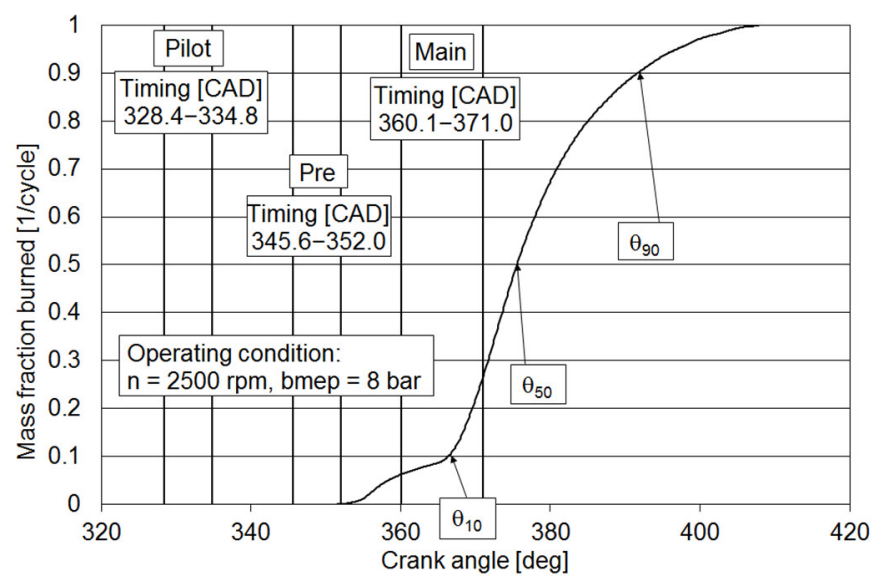

Figure 4. Example of mass fraction burned and related combustion parameters.

\subsection{Investigation Programme}

The selection of working conditions referred to part load engine operation, considering low and medium levels of brake mean effective pressure (bmep) and rotational speed $\mathrm{n}$ (respectively 2, 5 and 8 bar; 1500, 2000 and $2500 \mathrm{rpm}$ ). These points are representative of type approval and real-world driving conditions in urban and extra-urban modes for cars fitted with the tested engine [1].

For each working condition, four sets of experimental modes were investigated, summarised in Table 2.

Table 2. Description of experimental activities.

\begin{tabular}{cc}
\hline Tests & Description \\
\hline Set 1 & HP EGR trade-off \\
\hline Set 2 & HP EGR + LP EGR + VNT control \\
\hline Set 3 & Selected modes from set $2+$ prail $_{\text {control }}$ \\
\hline Set 4 & Standard level of HP EGR + prail control \\
\hline
\end{tabular}


In Set 1, the high-pressure EGR circuit was activated and managed, applying a typical trade-off from zero levels up to an EGR rate higher than the standard level, eventually limited by a smoke emission around 3 FSN. Tables 3 and 4 present control values for relative air-fuel ratio applied in the ECU map, the corresponding levels of EGR rate and CDI and the measured levels of intake quantities.

The different method for turbine control is apparent in the two tables, as Variable Nozzle Turbine (VNT) opening degree was kept at a constant value in points No.1 and 2 (open loop scheme), leading to variations of intake pressure according to the opening of the EGR valve (Table 3). In point No.3, intake pressure was constant (closed-loop scheme), resulting in lower values of $A_{V N T}$ when increasing EGR rate, to achieve $p_{i}$ target level (Table 4).

Table 3. Schedule of experimental activities for test Set 1 and average values of operating parameters (operating conditions No.1 and 2).

\begin{tabular}{|c|c|c|c|c|c|c|}
\hline $\begin{array}{c}\text { Operating Condition } \\
\text { ID }=\mathbf{n} \times \text { bmep } \\
{[\mathrm{rpm} \times \text { bar }]}\end{array}$ & Relative Air-Fuel Ratio & $\begin{array}{c}\mathbf{f}_{\mathrm{EGR}} \\
{[\%]}\end{array}$ & $\begin{array}{l}\text { CDI } \\
{[-]}\end{array}$ & $\underset{[b a r]}{p_{i}}$ & $\begin{array}{c}\mathbf{M}_{\mathbf{i}} \\
{[\mathrm{kg} / \mathrm{h}]}\end{array}$ & $\stackrel{\mathbf{t}_{\mathbf{i}}}{\left[{ }^{\circ} \mathrm{C}\right]}$ \\
\hline \multirow{6}{*}{ No. $1=1500 \times 2$} & 3.3 & 0 & 0 & 1.134 & 59.1 & 27.9 \\
\hline & 3.2 & 15.8 & 0.191 & 1.118 & 65.9 & 31.5 \\
\hline & 3.0 & 18.8 & 0.236 & 1.105 & 64.2 & 34.2 \\
\hline & $2.9^{1}$ & 22.1 & 0.291 & 1.092 & 62.1 & 37.5 \\
\hline & 2.7 & 25.7 & 0.354 & 1.079 & 61.0 & 41.1 \\
\hline & \multicolumn{6}{|c|}{$\begin{aligned} \mathrm{SOI}_{\text {pilot }}= & 20.1 \mathrm{CAD} \text { BTDC, } \mathrm{SOI}_{\text {pre }}=8.0 \mathrm{CAD} \text { BTDC, } \mathrm{SOI}_{\text {main }}=1.3 \mathrm{CAD} \text { ATDC, } \\
& \mathrm{Q}_{\text {pilot }}=\mathrm{Q}_{\text {pre }}=1 \mathrm{~mm}^{3} / \text { stroke, } \mathrm{p}_{\text {rail }}=370 \mathrm{bar}, \mathrm{A}_{\mathrm{VNT}}=1.4 \%\end{aligned}$} \\
\hline \multirow{6}{*}{ No. $2=2000 \times 5$} & 2.5 & 0 & 0 & 1.513 & 106.5 & 25.2 \\
\hline & 2.2 & 13.4 & 0.160 & 1.433 & 105.0 & 31.4 \\
\hline & 2.0 & 17.8 & 0.224 & 1.390 & 101.1 & 36.6 \\
\hline & $1.8^{1}$ & 22.8 & 0.306 & 1.341 & 95.7 & 43.6 \\
\hline & 1.6 & 27.6 & 0.396 & 1.299 & 92.2 & 51.6 \\
\hline & \multicolumn{6}{|c|}{$\begin{array}{c}\mathrm{SOI}_{\text {pilot }}=25.1 \mathrm{CAD} \text { BTDC, } \mathrm{SOI}_{\text {pre }}=10.7 \mathrm{CAD} \mathrm{BTDC}, \mathrm{SOI}_{\text {main }}=1.1 \mathrm{CAD} \text { ATDC, } \\
\mathrm{Q}_{\text {pilot }}=\mathrm{Q}_{\text {pre }}=1 \mathrm{~mm}^{3} / \text { stroke}, \mathrm{p}_{\text {rail }}=588 \mathrm{bar}, \mathrm{A}_{\mathrm{VNT}}=7.6 \%\end{array}$} \\
\hline
\end{tabular}

Table 4. Schedule of experimental activities for test Set 1 and average values of operating parameters (operating condition No.3).

\begin{tabular}{|c|c|c|c|c|c|c|}
\hline $\begin{array}{l}\text { Operating Condition } \\
\text { ID }=\mathrm{n} \times \text { bmep } \\
{[\mathrm{rpm} \times \text { bar }]}\end{array}$ & Relative Air-Fuel Ratio & $\begin{array}{c}\mathbf{f}_{\mathrm{EGR}} \\
{[\%]}\end{array}$ & $\begin{array}{c}\text { CDI } \\
{[-]}\end{array}$ & $\begin{array}{c}\mathbf{M}_{\mathbf{i}} \\
{[\mathrm{kg} / \mathrm{h}]}\end{array}$ & $\mathbf{t}_{\mathbf{i}}\left[{ }^{\circ} \mathrm{C}\right]$ & $\begin{array}{c}\mathrm{A}_{\mathrm{VNT}} \\
{[\%]}\end{array}$ \\
\hline \multirow{6}{*}{ No. $3=2500 \times 8$} & 2.1 & 0.0 & 0 & 146.2 & 27.2 & 29.2 \\
\hline & 2.0 & 4.7 & 0.051 & 148.5 & 31.3 & 26.9 \\
\hline & 1.8 & 12.3 & 0.146 & 145.3 & 39.0 & 23.7 \\
\hline & $1.6^{1}$ & 18.1 & 0.231 & 137.3 & 50.3 & 18.8 \\
\hline & 1.5 & 19.9 & 0.260 & 135.9 & 55.2 & 17.1 \\
\hline & \multicolumn{6}{|c|}{$\begin{array}{c}\mathrm{SOI}_{\text {pilot }}=31.6 \text { CAD BTDC, } \mathrm{SOI}_{\text {pre }}=14.4 \text { CAD BTDC, } \mathrm{SOI}_{\text {main }}=0.1 \text { CAD ATDC, } \\
\mathrm{Q}_{\text {pilot }}=\mathrm{Q}_{\text {pre }}=1 \mathrm{~mm}^{3} / \text { stroke, } \mathrm{p}_{\text {rail }}=812 \mathrm{bar}, \mathrm{p}_{\mathrm{i}}=1.52 \mathrm{bar}\end{array}$} \\
\hline
\end{tabular}

Test Set 2 dealt with the simultaneous activation of high and low-pressure EGR circuits and the control of variable nozzle turbine, aiming at $\mathrm{NO}_{X}$ and fuel consumption reduction [20], while limiting penalties in soot emissions due to the increase of overall EGR rate compared to the standard level in Euro 5 configuration.

As presented in Table 5, different settings of control variables (relative air-fuel ratio, throttle valve position in the exhaust circuit, LP EGR valve opening degree, VNT opening degree/intake pressure) 
were actuated in the selected operating conditions. As already explained, the last two variables were referred to the open and closed-loop control schemes available for VNT management.

Table 5. Schedule of experimental activities for test Set 2.

\begin{tabular}{|c|c|c|c|}
\hline $\begin{array}{l}\text { Operating Condition } \\
\text { ID }=\mathrm{n} \times \text { bmep } \\
{[\mathrm{rpm} \times \text { bar }]}\end{array}$ & $\begin{array}{l}\text { Control Variables } \\
\text { (Fixed in Each Test) }\end{array}$ & Tests & $\begin{array}{l}\text { Control Variables (LP EGR } \\
\text { and VNT Control) }\end{array}$ \\
\hline \multirow{2}{*}{ No.1 $=1500 \times 2$} & $\begin{array}{l}\text { Relative air-fuel ratio } \\
\text { Exhaust throttle valve position }\end{array}$ & $\begin{array}{l}\text { Rel.AFR }=3.01-\mathrm{TV} \text { pos. } 1 \\
\text { Rel.AFR }=2.90^{1} \text {-TV pos. } 1^{1}, 2,3 \\
\text { Rel.AFR }=2.77-\mathrm{TV} \text { pos. } 1,2 \\
\text { Rel.AFR }=2.62-\mathrm{TV} \text { pos. } 1,2\end{array}$ & $\begin{array}{l}\text { LP EGR valve opening } \\
\text { VNT opening degree }\end{array}$ \\
\hline & \multicolumn{3}{|c|}{ 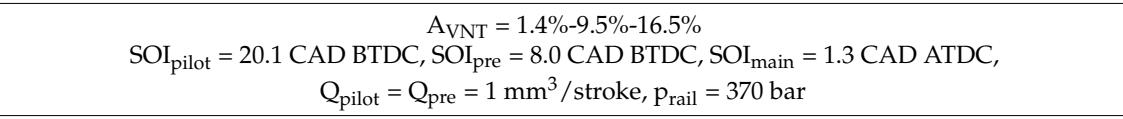 } \\
\hline \multirow{2}{*}{ No. $2=2000 \times 5$} & $\begin{array}{l}\text { Relative air-fuel ratio } \\
\text { Exhaust throttle valve position }\end{array}$ & $\begin{array}{l}\text { Rel.AFR }=1.94-\mathrm{TV} \text { pos. } 1 \\
\text { Rel.AFR }=1.80^{1} \text {-TV pos. } 1^{1}, 2,3 \\
\text { Rel.AFR }=1.67-\mathrm{TV}^{2} \text { pos. } 1,2\end{array}$ & $\begin{array}{l}\text { LP EGR valve opening } \\
\text { VNT opening degree }\end{array}$ \\
\hline & \multicolumn{3}{|c|}{$\begin{array}{c}\mathrm{A}_{\mathrm{VNT}}=7.6 \%-14.0 \%-17.0 \% \\
\mathrm{SOI}_{\text {pilot }}=25.1 \mathrm{CAD} \mathrm{BTDC}, \mathrm{SOI}_{\text {pre }}=10.7 \mathrm{CAD} \mathrm{BTDC}, \mathrm{SOI}_{\text {main }}=1.1 \mathrm{CAD} \\
\mathrm{ATDC}, \mathrm{Q}_{\text {pilot }}=\mathrm{Q}_{\text {pre }}=1 \mathrm{~mm}^{3} / \text { stroke, } \mathrm{p}_{\text {rail }}=588 \mathrm{bar}\end{array}$} \\
\hline \multirow[t]{2}{*}{ No. $3=2500 \times 8$} & $\begin{array}{l}\text { Relative air-fuel ratio } \\
\text { Exhaust throttle valve position } \\
\text { Intake pressure }\end{array}$ & $\begin{aligned} \text { Rel.AFR }= & 1.60 \text {-Intake press. }=1.48 \\
& \text { bar-TV pos. } 1 \\
\text { Rel.AFR }= & 1.60^{1} \text {-Intake press. }=1.52 \\
1,1.57 \text { bar-TV pos. } 0,1^{1} & \\
\text { Rel.AFR }= & 1.47 \text {-Intake press. }=1.52 \\
& \text { bar-TV pos. } 1\end{aligned}$ & LP EGR valve opening \\
\hline & $\begin{array}{r}\mathrm{SOI}_{\text {pilot }}=31.6 \mathrm{CAD} \mathrm{B} \\
\mathrm{Q}_{\mathrm{pi}}\end{array}$ & $\begin{array}{l}\mathrm{DC}, \mathrm{SOI}_{\mathrm{pre}}=14.4 \mathrm{CAD} \mathrm{BTDC}, \mathrm{SOI}_{\mathrm{mai}} \\
=\mathrm{Q}_{\text {pre }}=1 \mathrm{~mm}^{3} / \text { stroke, } \mathrm{p}_{\text {rail }}=812 \mathrm{ba}\end{array}$ & $=0.1 \mathrm{CAD}$ ATDC, \\
\hline
\end{tabular}

Referring to the throttle valve at the exhaust end, position 1 allowed us to obtain a pressure level at the turbine exit corresponding to a regenerated diesel particulate filter. To increase the mass flow rate from the low-pressure EGR loop, more closed positions were actuated ( 2 and 3 ), while setting 0 corresponded to a reduction of pressure along the exhaust circuit.

Therefore, in points No.1 and 2, relative AFR and TV position were selected for each test, where the first mode corresponded to the activation of the HP EGR loop (LP contribution $=0$ ). Then, the LP EGR valve was increasingly opened. When the maximum contribution from the LP EGR circuit was obtained, VNT control was added, opening the device to reduce exhaust back pressure.

As shown in Table 5, in point No.3, each test was characterised also by a constant value of intake pressure, while only LP EGR valve control allowed to modify engine behaviour.

Processing of the wide experimental database collected in test Set 2, allowed to select proper engine modes, as discussed in Reference [20]. These modes were characterised by a significant reduction in $\mathrm{NO}_{X}$ emissions, lower levels of fuel consumption, limited penalties in soot emissions and increased values of turbocharger speed, always referring to the standard Euro 5 configuration. Starting from the corresponding values of control variables, test Set 3 was then developed according to the levels presented in Table 6 . Two series of tests were scheduled for each operating condition to apply rail pressure control, aiming at reducing soot emissions and analysing the influence of this quantity on engine outputs and combustion parameters. 
Table 6. Schedule of experimental activities for test Set 3.

\begin{tabular}{|c|c|c|}
\hline $\begin{array}{l}\text { Operating Condition } \\
\text { ID }=\mathbf{n} \times \text { bmep } \\
{[\mathrm{rpm} \times \text { bar }]}\end{array}$ & Selected Values for Control Variables & $\begin{array}{l}\text { Rail Pressure } \\
\text { [bar] }\end{array}$ \\
\hline No.1 $=1500 \times 2$ & $\begin{array}{c}\text { Rel. } \mathrm{AFR}=2.62 \\
\text { TV position }=2 \\
\mathrm{DC} \\
\left(\mathrm{A}_{\mathrm{VNT}}=16.5 \text { and } 86 \%\right. \\
\end{array}$ & $\begin{array}{c}345(-6.75 \%) \\
370 \text { (standard level) } \\
395(+6.75 \%) \\
420+13.5 \%\end{array}$ \\
\hline No. $2=2000 \times 5$ & $\begin{array}{c}\text { Rel. } \mathrm{AFR}=1.80 \\
\mathrm{DC}_{\mathrm{VNT}}=82 \%\left(\mathrm{~A}_{\mathrm{VNT}}=17 \%\right) \\
\text { Exhaust throttle valve position }=1 \text { and } 3\end{array}$ & $\begin{array}{c}544(-7.5 \%) \\
588 \text { (standard level) } \\
632(+7.5 \%) \\
676(+15.0 \%)\end{array}$ \\
\hline No. $3=2500 \times 8$ & $\begin{array}{c}\text { Rel. AFR }=1.60 \\
\text { TV position }=0 \\
\text { Intake pressure }=1.520 \text { and } 1.570 \text { bar }\end{array}$ & $\begin{array}{l}747(-8.0 \%) \\
812 \text { (standard level) } \\
877(+8.0 \%)\end{array}$ \\
\hline
\end{tabular}

Test Set 4 was again related to rail pressure control, applying the same levels of the previous step to the standard condition. Tables 7 and 8 show the average values of the EGR rate, charge dilution index, intake quantities and VNT opening degree in the three operating conditions. As a matter of fact, slight variations of parameters were observed but they were generally included in the range of measurement uncertainties. Increasing the fuel pressure injection led to a decrease in fuel consumption, affecting the relative air fuel ratio; to keep this variable to its target level, a reduction in air mass flow rate was requested, obtained through an increase of HP EGR valve opening. This behaviour was generally confirmed in test modes but effects on parameters listed in Tables 7 and 8 were negligible. A higher influence was shown by $\mathrm{NO}_{X}$ and soot emissions, fuel consumption and combustion parameters, as will be discussed in the following section.

Table 7. Schedule of experimental activities for test Set 4 and average values of operating parameters (operating conditions No.1 and 2).

\begin{tabular}{|c|c|c|c|c|c|c|c|}
\hline $\begin{array}{c}\text { Operating Condition } \\
\text { ID }=\mathbf{n} \times \text { bmep } \\
{[\mathrm{rpm} \times \text { bar }]}\end{array}$ & $\begin{array}{c}\text { Relative } \\
\text { Air-Fuel } \\
\text { Ratio }\end{array}$ & $\begin{array}{c}\mathbf{f}_{\mathrm{EGR}} \\
{[\%]}\end{array}$ & $\begin{array}{l}\text { CDI } \\
{[-]}\end{array}$ & $\begin{array}{c}\mathbf{M}_{\mathbf{i}} \\
{[\mathrm{kg} / \mathrm{h}]}\end{array}$ & $\stackrel{\mathbf{t}_{\mathbf{i}}}{\left[{ }^{\circ} \mathrm{C}\right]}$ & $\begin{array}{c}\mathrm{p}_{\mathrm{i}} \\
{[\mathrm{bar}]}\end{array}$ & $\begin{array}{r}\text { prail } \\
{[\text { bar] }}\end{array}$ \\
\hline \multirow{5}{*}{ No. $1=1500 \times 2$} & \multirow{4}{*}{2.9} & \multirow{4}{*}{22.5} & \multirow{4}{*}{0.297} & \multirow{4}{*}{64.0} & \multirow{4}{*}{40.6} & \multirow{4}{*}{1.100} & 345 \\
\hline & & & & & & & 370 \\
\hline & & & & & & & 395 \\
\hline & & & & & & & 420 \\
\hline & \multicolumn{7}{|c|}{$\begin{array}{c}\mathrm{SOI}_{\text {pilot }}=20.1 \text { CAD BTDC, } \text { SOI }_{\text {pre }}=8.0 \text { CAD BTDC, } \text { SOI }_{\text {main }}=1.3 \text { CAD ATDC, } \\
\mathrm{Q}_{\text {pilot }}=Q_{\text {pre }}=1 \mathrm{~mm}^{3} / \text { stroke, }, \mathrm{A}_{\mathrm{VNT}}=1.4 \%\end{array}$} \\
\hline \multirow{5}{*}{ No. $2=2000 \times 5$} & \multirow{4}{*}{1.8} & \multirow{4}{*}{23.2} & \multirow{4}{*}{0.313} & \multirow{4}{*}{95.9} & \multirow{4}{*}{46.4} & \multirow{4}{*}{1.306} & 544 \\
\hline & & & & & & & 588 \\
\hline & & & & & & & 632 \\
\hline & & & & & & & 676 \\
\hline & \multicolumn{7}{|c|}{$\begin{array}{c}\mathrm{SOI}_{\text {pilot }}=25.1 \mathrm{CAD} \mathrm{BTDC} \mathrm{SOI}_{\text {pre }}=10.7 \mathrm{CAD} \text { BTDC, } \mathrm{SOI}_{\text {main }}=1.1 \mathrm{CAD} \text { ATDC, } \\
\mathrm{Q}_{\text {pilot }}=\mathrm{Q}_{\text {pre }}=1 \mathrm{~mm}^{3} / \text { stroke }, \mathrm{A}_{\mathrm{VNT}}=7.6 \%\end{array}$} \\
\hline
\end{tabular}


Table 8. Schedule of experimental activities for test Set 4 and average values of operating parameters (operating condition No.3).

\begin{tabular}{|c|c|c|c|c|c|c|c|}
\hline $\begin{array}{c}\text { Operating Condition } \\
\text { ID }=\mathbf{n} \times \text { bmep } \\
{[\mathrm{rpm} \times \text { bar }]}\end{array}$ & $\begin{array}{c}\text { Relative } \\
\text { Air-Fuel } \\
\text { Ratio }\end{array}$ & $\begin{array}{c}f_{E G R} \\
{[\%]}\end{array}$ & $\begin{array}{c}\text { CDI } \\
{[-]}\end{array}$ & $\begin{array}{c}\mathbf{M}_{\mathrm{i}} \\
{[\mathrm{kg} / \mathrm{h}]}\end{array}$ & $\stackrel{t_{i}}{\left[{ }^{\circ} \mathrm{C}\right]}$ & $\begin{array}{c}\mathbf{A}_{\mathrm{VNT}} \\
{[\%]}\end{array}$ & $\begin{array}{r}\text { prail } \\
\text { [bar] }\end{array}$ \\
\hline \multirow{4}{*}{ No. $3=2500 \times 8$} & \multirow{3}{*}{1.6} & \multirow{3}{*}{18.4} & \multirow{3}{*}{0.236} & \multirow{3}{*}{134.7} & \multirow{3}{*}{55.8} & \multirow{3}{*}{19.7} & 747 \\
\hline & & & & & & & 812 \\
\hline & & & & & & & 877 \\
\hline & \multicolumn{7}{|c|}{$\begin{array}{c}\mathrm{SOI}_{\text {pilot }}=31.6 \mathrm{CAD} \text { BTDC, } \mathrm{SOI}_{\text {pre }}=14.4 \text { CAD BTDC, } \mathrm{SOI}_{\text {main }}=0.1 \mathrm{CAD} \text { ATDC, } \\
\mathrm{Q}_{\text {pilot }}=\mathrm{Q}_{\text {pre }}=1 \mathrm{~mm}^{3} / \text { stroke }, \mathrm{p}_{\mathrm{i}}=1.52 \mathrm{bar}\end{array}$} \\
\hline
\end{tabular}

\section{Results and Discussion}

In the previous step of this study [1], the relationship between average engine quantities and combustion parameters were developed referring to test Sets 1 and 2. The main targets were the validation of available data through expected correlations and the prediction of further links, which may be applied for engine and sub-systems modelling, the design of experimental campaigns and the definition of control strategies.

Considering these targets and following the approach presented in Reference [33] and applied in Reference [34] for control purposes, linear correlations were tested, limiting the range of involved parameters in order to simplify the description of engine behaviour for each selected operating condition. Therefore, even if internal combustion engines are not linear systems, the goal of the applied method was to verify if observed trends could be fitted with linear relationships. This approach led also to a reduction of computational effort and to a simplification of functions inversion, if necessary.

The following step was to consider measured levels of engine quantities derived from test Sets 3 and 4, which corresponded to include fuel rail pressure among the control variables previously selected and tested. As a result, the number of parameters considered for the development of statistical links was further enlarged, thus giving additional justification to the linear approach.

In this section, a sample of the most significant results of the processing of average engine quantities, in-cylinder pressure diagrams, heat release curves and combustion parameters is presented and discussed, referring to the whole experimental database. In particular, the effects of heat released in the premixed phase of the main combustion, maximum of the rate of heat release, maximum of heat release rate first derivative, $50 \%$ heat released crank angle will be deepened, taking also into account mutual interactions.

The Figures present trends referring to the four sets. Where different curves were available (Set 2, Table 5), the best set for each operating condition was chosen according to the highest determination coefficient. In any case, a threshold of 0.7 for $\mathrm{R}^{2}$ was set to guide the selection of relationship to be presented and discussed, with a few exceptions.

The discussion starts from the analysis of the influence of rail pressure control on pressure diagrams and heat release curves, which also allows us to outline the general characteristics of these outcomes. The corresponding analysis presenting the effects of EGR systems and VNT control was included in Reference [1].

\subsection{Trends in Pressure Diagrams and Heat Release Curves}

Figures 5 and 6 present the behaviour of pressure diagrams and heat release when controlling rail pressure in operating conditions No.2 and No.3. Graphs are limited to the crank angle interval related to combustion TDC ( $\theta=360$ crank angle degrees) and refer to three selected modes listed in Tables 7 and 8, with the HP EGR system activated according to the standard level of relative AFR. The standard injection strategy was based on three events (pilot, pre and main injections), whose timings are reported in the figures. Pressure diagrams show two maximum values, the first related to 
the compression stroke and the combustion of fuel injected in pilot and pre-events, the second to the combustion of the main injection.

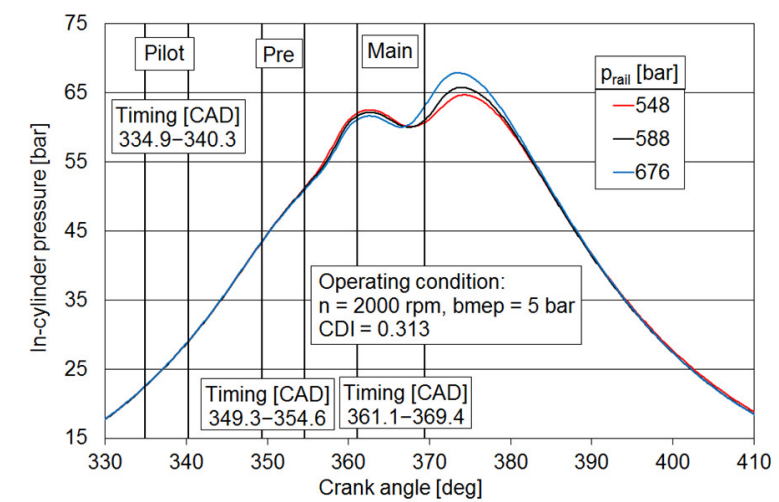

(a)

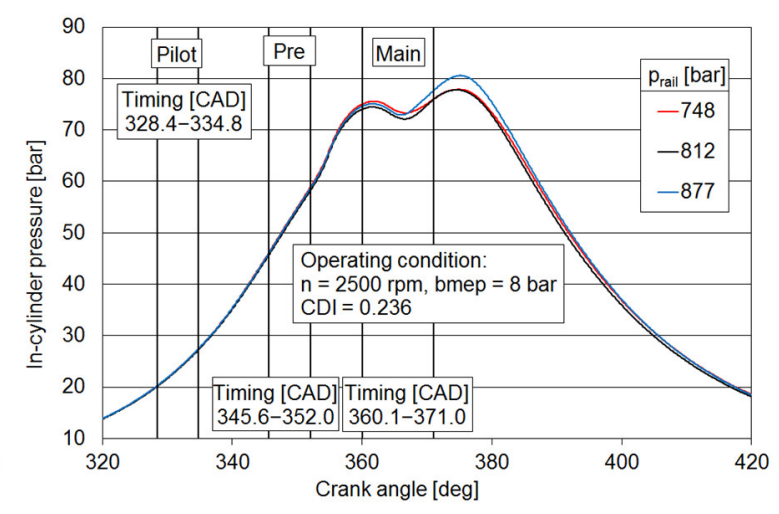

(b)

Figure 5. Influence of rail pressure control on pressure diagrams in operating condition No.2 (a) and No.3 (b).

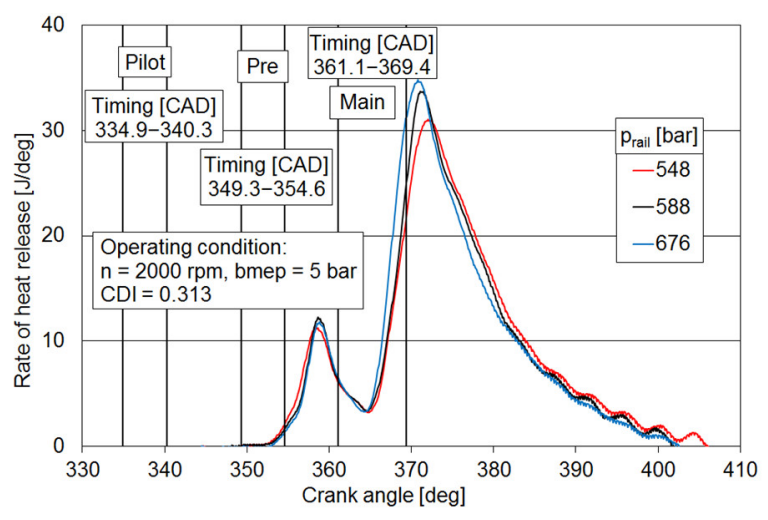

(a)

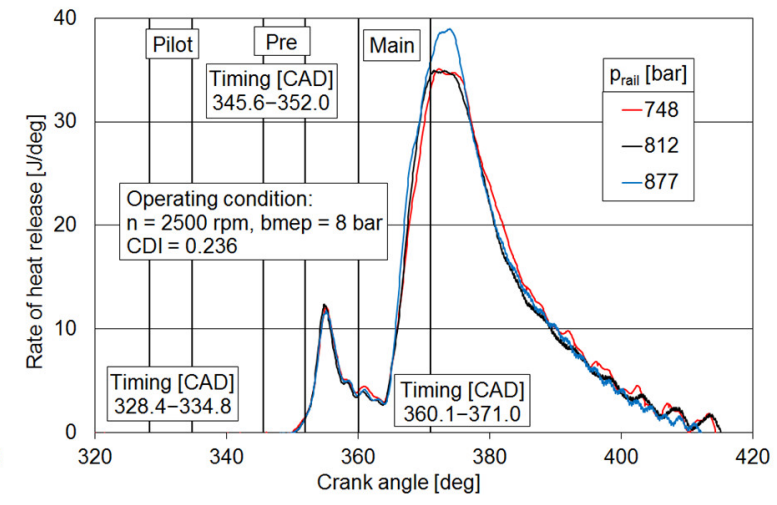

(b)

Figure 6. Influence of rail pressure control on the rate of heat release in operating condition No.2 (a) and No.3 (b).

The results outlined in Figures 5 and 6 are consistent with the discussion presented in Section 1.2, confirming that the behaviour of a turbocharged downsized engine is perfectly in line with that of different powertrain units. In both the operating conditions, the peak value of in-cylinder pressure was dependent on rail pressure, increasing when a higher value was actuated. The behaviour of heat release was also related to the injection strategy, while the influence of rail pressure was most apparent for the burning of fuel injected in the main event. As p pail increased, a shorter ignition delay was observed, with more rapid growth of heat release (which was quantified with the evaluation of the maximum of heat release rate first derivative) and a higher maximum level of heat release. As already mentioned, these results are related to the better atomisation of fuel droplets in the combustion chamber, achieved through the increase of injection pressure, which allows the enhancement of the mixture formation.

\subsection{Links with Heat Released in the Premixed Phase of Main Combustion}

Figure 7 presents the relationship between heat released in the premixed phase of the main combustion, maximum in-cylinder pressure (Figure 7a), soot emissions (Figure $7 \mathrm{~b}$ ) and $\mathrm{NO}_{\mathrm{X}}$ emissions (Figure 7c).

A direct correlation between $\mathrm{HR}_{\text {premix }}$ and $\mathrm{p}_{\mathrm{MAX}}$ is always apparent in Figure 7a. This was expected for reducing levels of EGR rate/CDI [1] but it was confirmed in all the tested modes. 
In test Sets 1 and 2, EGR rate and CDI were controlled. As their level increased, a longer ignition delay with slower combustion was observed, leading to a reduction of $\mathrm{HR}_{\text {premix }}$ and $\mathrm{p}_{M A X}$, which is related to the dilution effect of EGR technique [35,36]. When only the high-pressure EGR circuit was activated, this outcome was also related to the reduction of intake pressure and mass flow rate [20,21]. In set 2, the activation of LP EGR loop and the effects of VNT control led to counteracting influence, with different trends of intake quantities, anyway the overall effects on $\mathrm{HR}_{\text {premix }}$ and $\mathrm{P}_{\mathrm{MAX}}$ did not change.

In Sets 3 and 4, rail pressure control led to higher levels of $H_{R_{\text {premix }}}$ and $p_{\text {MAX }}$ (Figure 5), due to the enhancement of spray development and mixture formation already outlined in Section 1.2. As a consequence, the premixed phase of the combustion was improved.

This effect had further consequences, as shown in Figure $7 \mathrm{~b}$ referring to the inverse relationship between heat released in premixed phase and brake specific soot emissions. A lower soot emission is related to the enhanced premixed phase [37], as outlined for Sets 3 and 4 when applying higher prail levels. Similar behaviour was anyway observed for Sets 1 and 2 as a consequence of EGR control. As already mentioned, the increase of EGR rate had an inverse effect on premixed phase, weakening it and slowing down the whole combustion process. For the same reasons, brake specific $\mathrm{NO}_{\mathrm{X}}$ emissions (bsNOx) presented a direct relationship with $\mathrm{HR}_{\text {premix }}$, as depicted in Figure $7 \mathrm{c}$. In this case, a higher sensitivity was observed in Set 1, due to the activation of HP EGR circuit, while lower changes were obtained when a higher EGR rate was considered (Set 2) or when rail pressure control was applied (Sets 3 and 4). By comparing lines referred to operating condition No.3 in Sets 3 and 4, the effectiveness of LP EGR circuit can be observed, as significant reductions were achieved by adding its contribution to the overall EGR rate, as widely discussed in References [20,21].

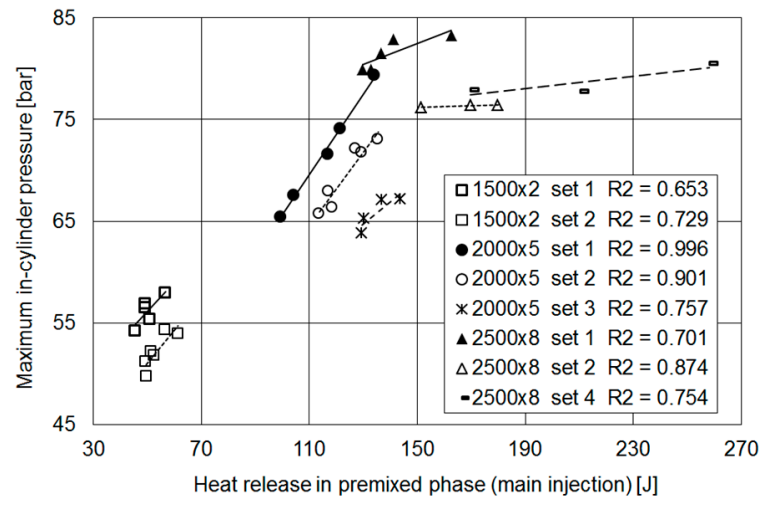

(a)

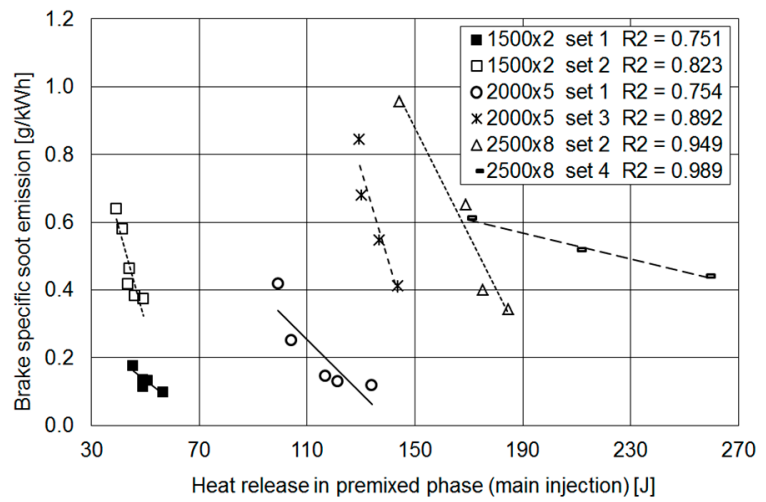

(b)

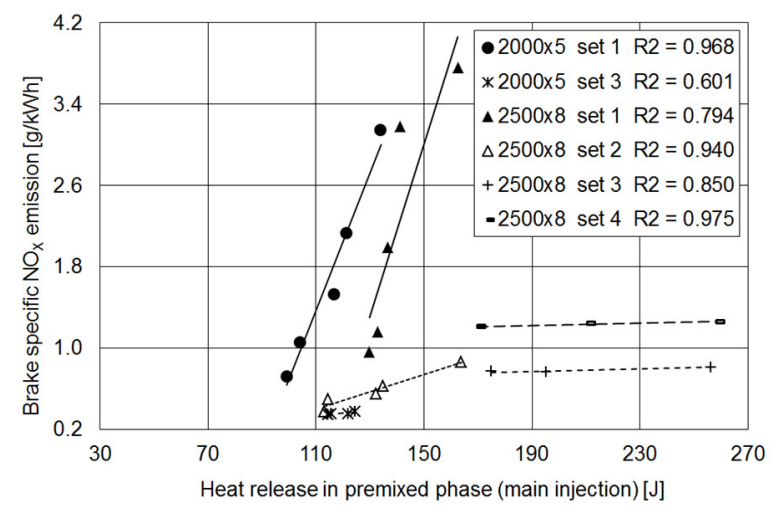

(c)

Figure 7. Relationship between $\mathrm{HR}_{\text {premix }}$ and $\mathrm{p}_{\mathrm{MAX}}(\mathbf{a}), \mathrm{bsS}(\mathbf{b}), \mathrm{bsNO} \mathrm{X}_{\mathrm{X}}(\mathbf{c})$ in different test sets. 


\subsection{Links with Maximum of Heat Release}

Figure 8 presents the relationship between the maximum of heat release with the maximum value of the first derivative of heat release rate (graph a), the centre of combustion (graph b) and the combustion duration (graph c).

The direct relationship between $\mathrm{RoHR}_{\mathrm{MAX}}$ and $(\mathrm{dRoHR} / \mathrm{d} \theta)_{\mathrm{MAX}}$ is related to the development of the premixed phase of the main combustion. In tests on HP EGR circuit control (Set 1), this link was not observed, as the increase of EGR rate led to a longer ignition delay and to a longer combustion duration if compared to the reference condition without recirculation [1]. When applying EGR from the low-pressure loop and VNT control (Set 2), the baseline condition was obtained with the standard HP EGR valve opening derived from the ECU map according to the engine manufacturer calibration. Referring to this working point, the development of the main combustion when activating LP EGR circuit outlined was different, as RoHR $\mathrm{MAX}$ and (dRoHR/d $)_{\text {MAX }}$ presented a slight increase. This behaviour may be justified considering the better mixing between air and recirculated gases occurring in the longer low-pressure EGR circuit, as also discussed in Reference [1] referring to pressure diagrams and heat release curves. As a consequence, the results for Set 2 are reported in Figure 8 a for the three tested operating conditions.

The rail pressure increase in Sets 3 and 4 led to the enhancement of premixed phase of the main combustion, in which the rise of both the presented quantities was obtained through the better spray development and penetration and the faster mixture formation already outlined.

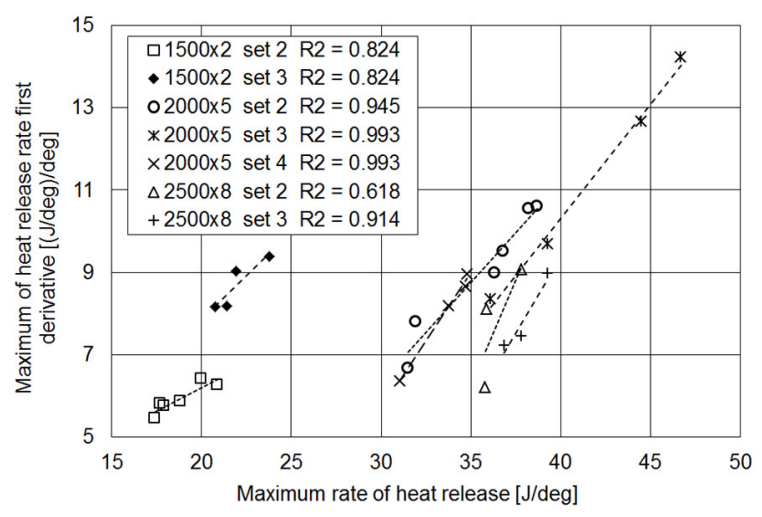

(a)

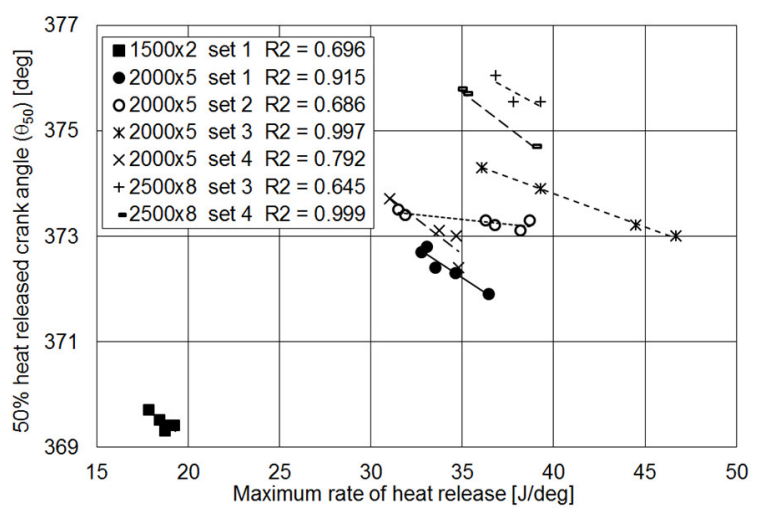

(b)

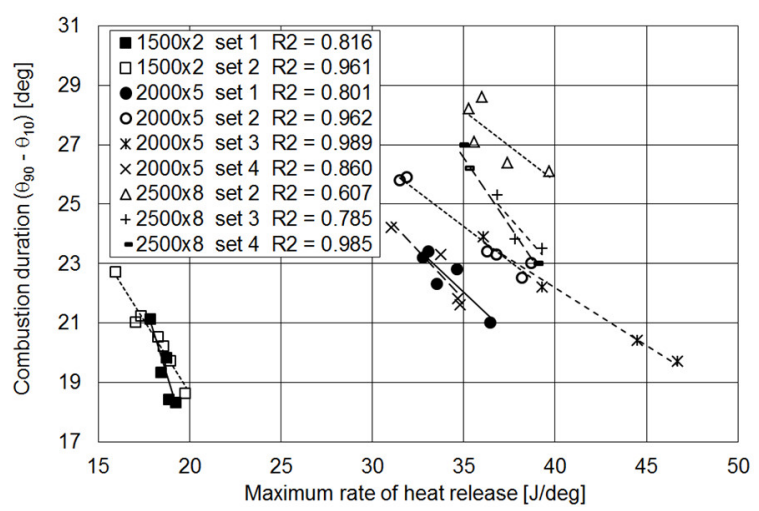

(c)

Figure 8. Relationship between $\operatorname{RoHR}_{\mathrm{MAX}}$ and $(\mathrm{dRoHR} / \mathrm{d} \theta)_{\mathrm{MAX}}(\mathbf{a}), \theta_{50}(\mathbf{b}),\left(\theta_{90}-\theta_{10}\right)(\mathbf{c})$ in different test sets.

One further consequence of the enhanced mixture formation and combustion is the shift of crank angle corresponding to $50 \%$ of heat release $\left(\theta_{50}\right)$ towards the TDC position, observed in Figure $8 \mathrm{~b}$ for Sets 3 and 4, when the rail pressure increased and higher values of maximum heat release were 
observed. In Set 1, this outcome was obtained when lower EGR rates were actuated, while in Set 2 when a prevailing share was due to the LP EGR loop, as previously discussed.

The same conclusions can be applied to the combustion duration $\left(\theta_{90}-\theta_{10}\right)$ shown in Figure $8 \mathrm{c}$. Changes in the premixed phase of the main combustion affected the whole combustion process, modifying the overall duration.

\subsection{Links with Maximum of Heat Release Rate First Derivative}

Figure 9 presents the correlations between the maximum value of the first derivative of heat release rate and the centre of combustion (Figure 9a), the combustion noise indicator (Figure 9b) and the second maximum of pressure derivative (Figure 9c).

Referring to Figure 9a, despite the observed trends can be considered a consequence of the link between the two quantities and $\mathrm{ROHR}_{\mathrm{MAX}}$ reported in Figure 8a,c, the linear relationship is confirmed also between them. The inverse link is related to the fact that an increase in $(\mathrm{dRoHR} / \mathrm{d} \theta)_{\mathrm{MAX}}$ is due to a higher level of rail pressure for Sets 3 and 4 , moving $\theta_{50}$ closer to TDC, reducing its value because faster combustion occurred. For Set 2, this behaviour is related to a higher contribution from the low-pressure loop, as already outlined in the previous paragraphs.

As far as combustion noise indicator is concerned (Figure 9b), its rise is related to the faster combustion (at least in the premixed phase) achieved with rail pressure control (Sets 3 and 4), for a lower level of the EGR rate from the HP circuit (Set 1) or higher LP proportion (Set 2).

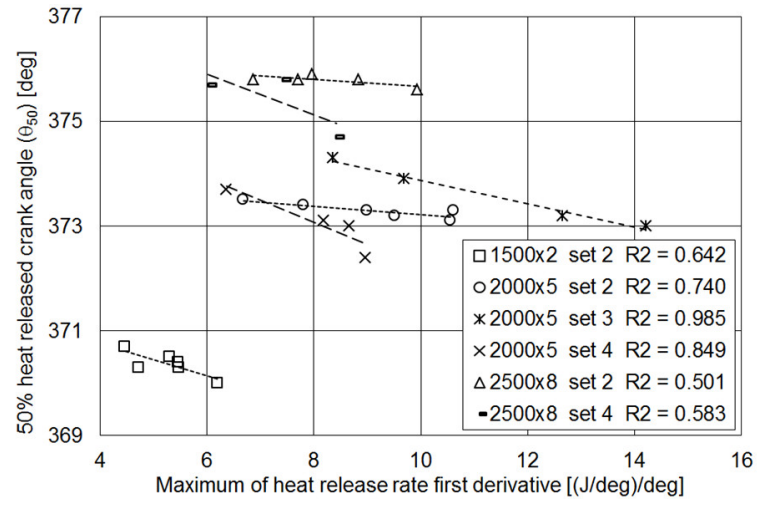

(a)

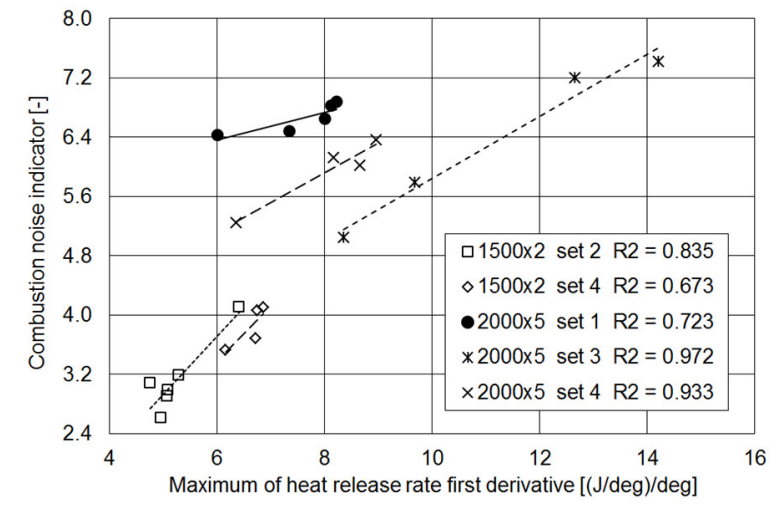

(b)

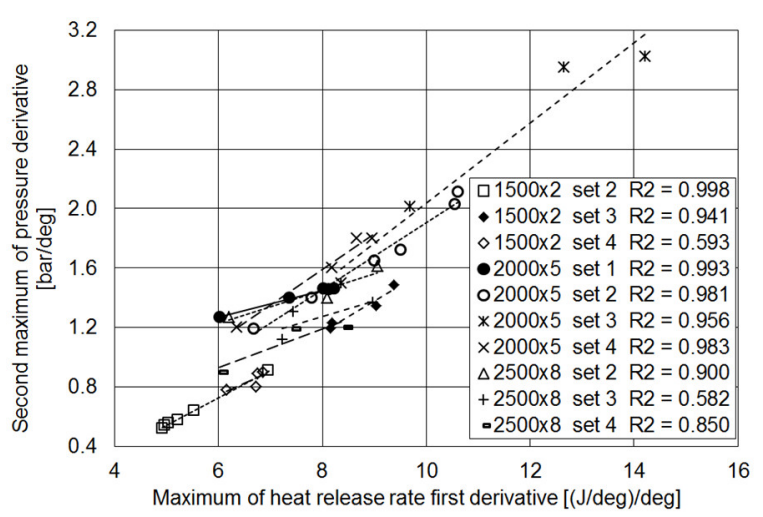

(c)

Figure 9. Relationship between $(\mathrm{dRoHR} / \mathrm{d} \theta)_{\mathrm{MAX}}$ and $\theta_{50}(\mathbf{a}), \mathrm{I}_{\mathrm{n}}(\mathbf{b}),(\mathrm{dp} / \mathrm{d} \theta)_{\mathrm{MAX} 2}(\mathbf{c})$ in different test sets.

The trends of the second maximum of pressure derivative as a function of ( $d R o H R / d \theta)_{\operatorname{MAX}}$ shown in Figure 9c are expected, due to the influence of RoHR $\mathrm{MAX}_{\mathrm{X}}$ on the maximum levels of heat release rate first derivative (Figure $7 \mathrm{a}$ ) and on $(\mathrm{dp} / \mathrm{d} \theta)_{\operatorname{MAX} 2}$ (not shown). However, it is interesting to 
note the large number of data sets showing high levels of determination coefficient for this relationship (which is not true for $I_{n}$, as shown in Figure $9 b$ ) and the fact that it would be possible to identify a single correlation among all the available data. The first result is related to the definition of $I_{n}$ (Equation (8)) where the first maximum of pressure derivative also appears. This quantity is associated with the combustion of fuel injected during pilot and pre-injections (Figure 2). Taking into account that slight or no variations of $(\mathrm{dp} / \mathrm{d} \theta)_{\operatorname{MAX} 1}$ values were observed when modifying the different control variables (as can be deduced from Figure 6 and discussed in Reference [1]), it can be concluded that the description of combustion noise issues may be developed referring only to the second maximum $(\mathrm{dp} / \mathrm{d} \theta)_{\operatorname{MAX} 2}$. Further details will be added discussing the direct link between combustion noise indicator and $(\mathrm{dp} / \mathrm{d} \theta)_{\mathrm{MAX} 2}$, reported in Figure 11.

\subsection{Influence of $50 \%$ Heat Released Crank Angle}

Figure 10 presents the relationships between the centre of combustion and peak in-cylinder pressure (Figure 10a), combustion duration (Figure 10b), brake specific fuel consumption (Figure 10c) and soot emissions (Figure 10d).

The reasons for variations of crank angle corresponding to $50 \%$ of heat release were already discussed in the previous section with reference to Figures 8 and 9. The trends reported in Figure 10 are therefore a further consequence of variables controlled in the different experimental campaigns.

From Figure 10a, it is clear that the combustion development was less favourable to achieve a higher level of in-cylinder pressure when $\theta_{50}$ moved far from the TDC. This was due to the increase of EGR rate in Sets 1 and 2 or to the decrease of rail pressure in sets 3 and 4 . The same result was observed in Reference [38]. Similar trends were observed for the three operating conditions in the different testing modes, with high levels of determination coefficient. The only exception was related to HP trade-off in point $2000 \times 5$, due to the wider range of EGR rate, leading to large variations of intake pressure and charge mass flow rate.

For the same reasons, the shift of combustion centre along the expansion stroke led to the longer combustion duration shown in Figure 10b when controlling CDI (increasing it in Sets 1 and 2) or actuating lower levels of $p_{\text {rail }}$ in Sets 3 and 4.

Figure 10c shows that retarding the combustion process within the expansion stroke led to an increase of bsfc. It is interesting to note that in each set presented in this graph, variations between the minimum and maximum levels are above the measurement uncertainties. In fact, the maximum uncertainty on measured levels of bsfc is around 1.5\% [20], while observed changes in Figure 10c are above $2 \%$ (point No.1), about 1.6\% (point No.2) and between 1.7-5.3\% (point No.3). The corresponding variations of $\theta_{50}$ ranged from 0.5 up to $1.5 \mathrm{CAD}$, that is, slight changes in the combustion centre position had a significant consequence on fuel consumption.

Similar results are presented in Reference [38,39] when considering diesel oil, even if referring to indicated quantities. In the first study, increases of three CAD of the combustion centre position (with reference to the level corresponding to the maximum indicated thermal efficiency) led to average variations of about $2 \%$ in efficiency and fuel consumption. The second investigation reported a first isfc increase of about $5 \%$ when moving $\theta_{50}$ of one $C A D$ along the expansion stroke and a second rise around $4 \%$ for a further retard of two CAD.

From Figure 10d, it is apparent that the lowest levels of soot emissions are obtained when $\theta_{50}$ is closer to TDC for each test set, because of the reduced or zero EGR rate or the maximum value of rail pressure. These conditions led to a shorter combustion duration and, for Sets 3 and 4, to an enhanced premixed phase of the combustion, which reduced bsS emissions [37]. 


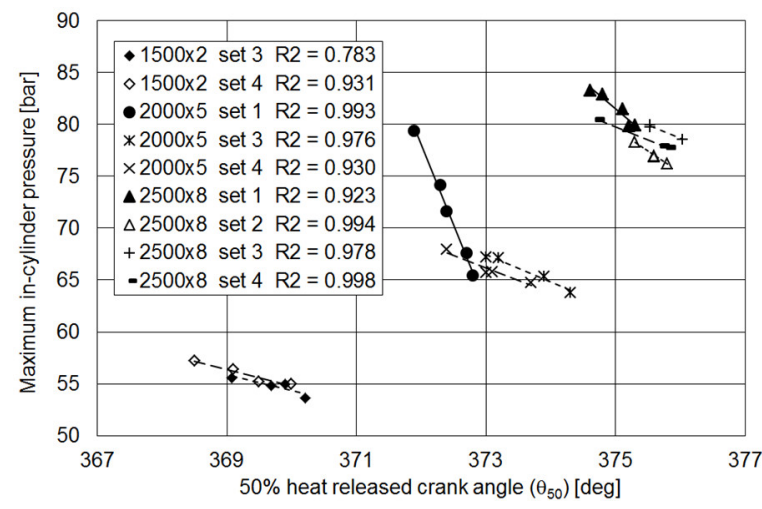

(a)

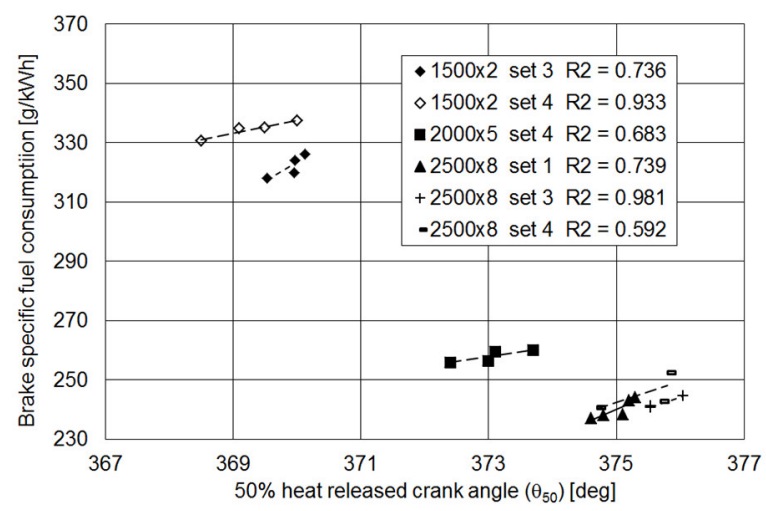

(c)

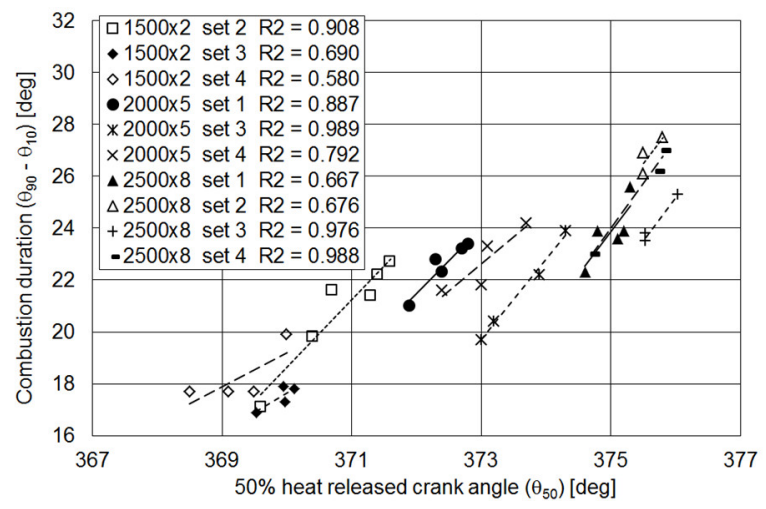

(b)

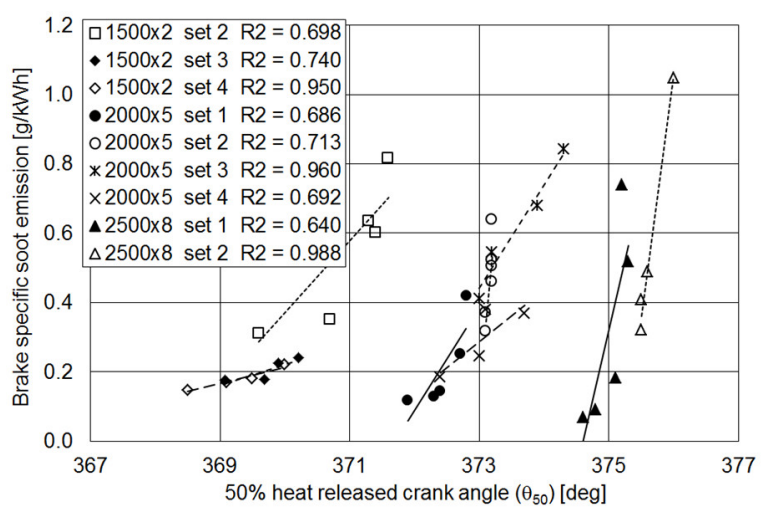

(d)

Figure 10. Relationship between $\theta_{50}$ and $\operatorname{p}_{\operatorname{MAX}}(\mathbf{a}),\left(\theta_{90}-\theta_{10}\right)(\mathbf{b})$, bsfc $(\mathbf{c})$, bsS $(\mathbf{d})$ in different test sets.

The shift of $\theta_{50}$ along the expansion stroke is related to worst conditions inducing soot formation, with lower oxygen availability and a prevailing contribution of diffusive combustion, which is commonly related to this emission.

Graph 10d includes a large number of sets showing the link within the combustion centre and bsS, which also presented wide variations of bsS emissions, mainly when controlling the EGR rate. As happened for the other parameters reported in Figure 10, in Reference [38] the same relationship between $\theta_{50}$ and bsS was presented.

\subsection{Links with Combustion Noise Indicator}

Figure 11 presents the link between the combustion noise indicator and the second maximum of pressure derivative (Figure 11a) and $\mathrm{NO}_{X}$ emissions (Figure 11b). The main combustion was majorly responsible for the combustion noise, as shown by the direct correlation between the two quantities and by the different behaviour of the first maximum of pressure derivative discussed in Reference [1].

In Sets 1 and 2, CDI generally had a prevailing influence on combustion noise, leading to a reduction of related parameters as a consequence of lower oxygen availability and the slower development of combustion. The same behaviour was observed in References [40-42], proving that $I_{n}$ can describe changes in noise when controlling variables affecting this aspect.

In Sets 3 and 4, rail pressure was responsible for the observed trends, as a consequence of the different effects related to its increase discussed in Sections 1.2 and 3.1. A similar outcome was shown in Reference [43], where the link between rail pressure control, pressure rise rate and combustion noise was presented referring to an automotive diesel engine with a displacement of $1.7 \mathrm{dm}^{3}$, a common rail fuel injection equipment and a volumetric compression ratio very close to the engine tested in this work. 


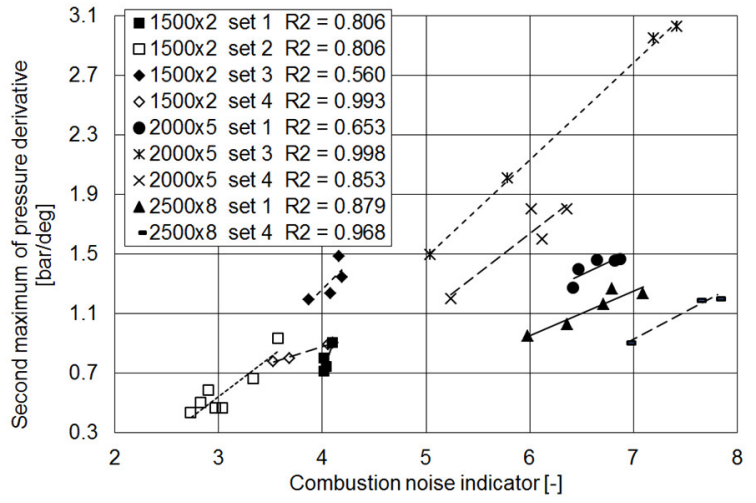

(a)

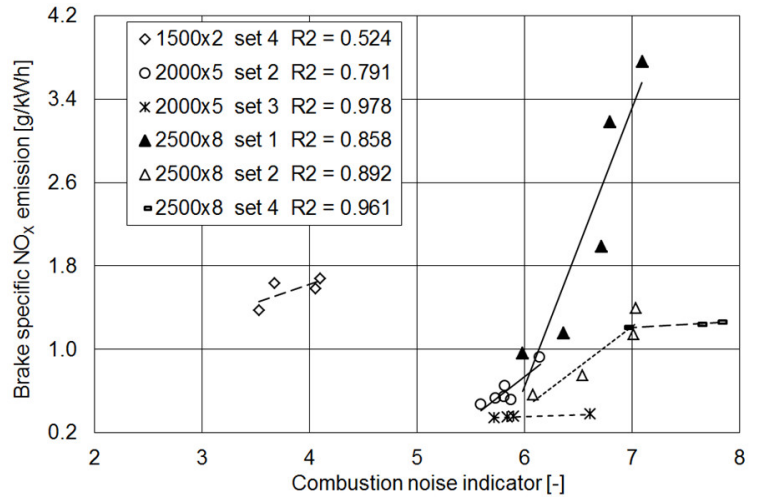

(b)

Figure 11. Relationship between $I_{n}$ and $(d p / d \theta)_{\operatorname{MAX} 2}(\mathbf{a}), b S N O_{X}(b)$ in different test sets.

Taking into account the linear relationship shown in Figure 11a and the minor variations in the combustion of the pilot injections shown in Figures 5 and 6 and discussed in Reference [1], it can be concluded that $(\mathrm{dp} / \mathrm{d} \theta)_{\operatorname{MAX} 2}$ may be applied to describe combustion noise changes when controlling the main engine subsystems.

The direct relationship between combustion noise indicator and $\mathrm{NO}_{\mathrm{X}}$ emissions, presented in Figure $11 \mathrm{~b}$ for different test sets, confirmed the similar effects on these quantities obtained by increasing EGR rate (Sets 1 and 2) or by reducing rail pressure (Sets 3 and 4).

\section{Conclusions}

The availability of a large experimental database on the application of control strategies to fuel injection, turbocharging and hybrid EGR systems of an automotive downsized diesel engine allowed us to develop an extended analysis of combustion parameters, their reciprocal interactions and links with engine quantities. Trends were then analysed referring to variables controlled during the experimental campaigns and relationships were statistically defined.

A proper selection of the most representative outcomes of this investigation allowed to outline the following hints.

- Generally, controlling CDI and $\mathrm{p}_{\text {rail }}$ led to inverse effects, as increasing the amount of recirculated gases corresponded to the decrease of rail pressure in terms of observed variations of engine average quantities and combustion parameters.

- Test Sets 1 and 2 were mainly influenced by EGR rate/Charge Dilution Index control, with significant differences when adding recirculated gases from low-pressure circuit (Set 2) to conventional high-pressure EGR (Set 1). This was related to the effects of LP contribution, lowering charge temperature at the engine intake and allowing a better mixing between air and recirculated gases.

- Test Sets 3 and 4 showed the influence of rail pressure control, as the reduction of average fuel droplets dimensions and better spray development enhanced mixture formation and the development of combustion, especially in the premixed phase, reducing ignition delay and increasing maximum levels of pressure, heat release and its first derivative.

- The expected effects of rail pressure control on fuel consumption, $\mathrm{NO}_{\mathrm{X}}$ and soot emissions and combustion noise were observed, as well as the relationship between these quantities and combustion parameters such as $\theta_{50}$ and $H_{\text {premix }}$. This outcome validated the calculation procedure of the selected combustion parameters, which could be affected by the standard injection strategy based on three events and the main injection timing, resulting in a trend of rate of heat release where premixed and diffusive phases were not clearly separated. 
- Combustion noise indicator proved to be a suitable quantity to describe noise issues, as it was affected by control variables (CDI and $\mathrm{p}_{\text {rail }}$ ) according to findings discussed in the literature. A further simplification may be applied to this topic, as the linear relationship between $\mathrm{I}_{\mathrm{n}}$ and $(\mathrm{dp} / \mathrm{d} \theta)_{\operatorname{MAX} 2}$ (i.e., the maximum of in-cylinder pressure derivative occurring during the combustion related to the main injection) suggests to consider only the second quantity. This means to neglect the effects of $(\mathrm{dp} / \mathrm{d} \theta)_{\operatorname{MAX} 1}$ (i.e., the maximum of in-cylinder pressure derivative occurring during the combustion related to the pilot injections), which was marginally affected by control variables.

As a general conclusion, the availability of combustion parameters derived from pressure diagrams and rate of heat release curves proved to be a powerful tool for an extended analysis of combustion process and its link to the engine behaviour, in terms of operating, energy and environmental quantities. This method will be applied to the comparison of different alternative fuels which will be tested on the available diesel engine, integrating outcomes related to changes in fuel consumption and exhaust emissions.

Funding: This research received no external funding.

Conflicts of Interest: The author declares no conflict of interest.

\section{Nomenclature}

$\begin{array}{ll}\text { Notations } & \\ \text { bmep } & \text { brake mean effective pressure } \\ \text { bsfc } & \text { brake specific fuel consumption } \\ \text { bsNOX } & \text { brake specific NOX emission } \\ \text { bsS } & \text { brake specific soot emission } \\ \mathrm{f} & \text { mass flow fraction } \\ \mathrm{k} & \text { ratio of specific heats } \\ \text { imep } & \text { indicated mean effective pressure } \\ \text { isfc } & \text { indicated specific fuel consumption } \\ \mathrm{n} & \text { rotational speed } \\ \mathrm{p} & \text { pressure } \\ \mathrm{t} & \left.\text { temperature [ }{ }^{\circ} \mathrm{C}\right] \\ \mathrm{A} & \text { opening degree } \\ \text { AFR } & \text { air-fuel ratio } \\ \text { BDC } & \text { bottom dead centre } \\ \text { CAD } & \text { crank angle degree } \\ \text { CDI } & \text { Charge Dilution Index } \\ \text { DC } & \text { duty-cycle } \\ \text { DI } & \text { direct injection } \\ \text { ECU } & \text { electronic control unit } \\ \text { EGR } & \text { exhaust gas recirculation } \\ \text { FSN } & \text { Filter Smoke Number } \\ \text { HP } & \text { high-pressure } \\ \text { HR } & \text { heat release } \\ \text { I } & \text { combustion indicator } \\ \text { LP } & \text { low-pressure } \\ \text { M } & \text { mass flow rate } \\ \text { PM } & \text { Particulate Matter } \\ \text { Q } & \text { injected quantity, heat } \\ \text { RoHR } & \text { rate of heat release } \\ \text { S } & \text { soot, nozzle ring push rod displacement } \\ & \end{array}$




$\begin{array}{ll}\text { SOI } & \text { start of injection } \\ \text { TDC } & \text { top dead centre } \\ \text { TV } & \text { exhaust throttle valve } \\ \text { V } & \text { instantaneous cylinder volume } \\ \text { VNT } & \text { variable nozzle turbine } \\ \text { X } & \text { volumetric concentration } \\ \theta & \text { crank angle } \\ \Delta & \text { variation } \\ \text { Subscripts } & \\ \text { a } & \text { air, ambient } \\ \text { f } & \text { fuel } \\ \text { i } & \text { intake } \\ \text { idle } & \text { engine idling condition } \\ \text { e } & \text { exhaust } \\ \text { main } & \text { referred to the main injection } \\ \mathrm{n} & \text { noise } \\ \text { pilot } & \text { referred to pilot injection } \\ \text { pre } & \text { referred to pre injection } \\ \text { premix } & \text { premixed combustion mode } \\ \text { rail } & \text { common rail } \\ \text { CO2 } & \text { carbon dioxide } \\ \text { EGR } & \text { exhaust gas recirculation } \\ \text { HP } & \text { high-pressure } \\ \text { LP } & \text { low-pressure } \\ \text { MAX } & \text { maximum } \\ \text { MIN } & \text { minimum } \\ \text { O2 } & \text { oxygen } \\ \text { VNT } & \text { variable nozzle turbine } \\ & \end{array}$

\section{References}

1. Zamboni, G. A study on combustion parameters in an automotive turbocharged diesel engine. Energies 2018, 11, 2531. [CrossRef]

2. Li, G.; Zhang, C.; Li, Y. Effects of diesel injection parameters on the rapid combustion and emissions of an HD common-rail diesel engine fueled with diesel-methanol dual-fuel. Appl. Therm. Eng. 2016, 108, 1214-1225. [CrossRef]

3. Barnstedt, K.; Ratzberger, R.; Grabner, P.; Eichlseder, H. Thermodynamic investigation of different natural gas combustion processes on the basis of a heavy-duty engine. Int. J. Engine Res. 2016, 17, 28-34. [CrossRef]

4. Pielecha, I.; Wisłocki, K.; Cies'lik, W.; Bueschke, W.; Skowron, M.; Fiedkiewicz, Ł. Application of IMEP and MBF50 indexes for controlling combustion in dual-fuel reciprocating engine. Appl. Therm. Eng. 2018, 132, 188-195. [CrossRef]

5. Ge, J.C.; Yoon, S.K.; Kim, M.S.; Choi, N.J. Application of Canola Oil Biodiesel/Diesel Blends in a Common Rail Diesel Engine. Appl. Sci. 2017, 7, 34. [CrossRef]

6. Chen, H.; Zhang, P.; Liu, Y. Investigation on combustion and emission performance of a common rail diesel engine fueled with diesel-ethylene glycol dual fuel. Appl. Therm. Eng. 2018, 142, 43-55. [CrossRef]

7. Nazemi, M.; Shahbakhti, M. Modeling and analysis of fuel injection parameters for combustion and performance of an RCCI engine. Appl. Energy 2016, 165, 135-150. [CrossRef]

8. Shibata, G.; Ogawa, H.; Amanuma, Y.; Okamoto, Y. Optimization of multiple heat releases in pre-mixed diesel engine combustion for high thermal efficiency and low combustion noise by a genetic-based algorithm method. Int. J. Engine Res. 2018, 1-15. [CrossRef]

9. Mao, B.; Yao, M.; Zheng, Z.; Li, Y.; Liu, H.; Yan, B. Effects of Dual Loop EGR on Performance and Emissions of a Diesel Engine. SAE Int. 2015. [CrossRef] 
10. Kim, J.; Bae, C. Emission reduction through internal and low-pressure loop exhaust gas recirculation configuration with negative valve overlap and late intake valve closing strategy in a compression ignition engine. Int. J. Engine Res. 2017, 18, 973-990. [CrossRef]

11. Agarwal, A.K.; Dhar, A.; Gupta, J.G.; Kim, W.I.; Lee, C.S.; Park, S. Effect of fuel injection pressure and injection timing on spray characteristics and particulate size-number distribution in a biodiesel fuelled common rail direct injection diesel engine. Appl. Energy 2014, 130, 212-221. [CrossRef]

12. Du, W.; Zhang, Q.; Zhang, Z.; Lou, J.; Bao, W. Effects of injection pressure on ignition and combustion characteristics of impinging diesel spray. Appl. Energy 2018, 226, 1163-1168. [CrossRef]

13. Agarwal, A.K.; Gupta, J.G.; Maurya, R.K.; Kim, W.I.; Lee, S.; Lee, C.S.; Park, S. Spray evolution, engine performance, emissions and combustion characterization of Karanja biodiesel fuelled common rail turbocharged direct injection transportation engine. Int. J. Engine Res. 2016, 17, 1092-1107. [CrossRef]

14. Syed Aalam, C.; Saravanan, C.G.; Prem Anand, B. Impact of high fuel injection pressure on the characteristics of CRDI diesel engine powered by mahua methyl ester blend. Appl. Therm. Eng. 2016, 106, 702-711. [CrossRef]

15. Ashok, B.; Nanthagopal, K.; Chaturvedi, B.; Sharma, S.; Thundil Karuppa Raj, R. A comparative assessment on Common Rail Direct Injection (CRDI) engine characteristics using low viscous biofuel blends. Appl. Therm. Eng. 2018, 145, 494-506. [CrossRef]

16. Xu, L.; Baib, X.; Jiac, M.; Qiana, Y.; Qiaoa, X.; Lu, X. Experimental and modeling study of liquid fuel injection and combustion in diesel engines with a common rail injection system. Appl. Energy 2018, 230, 287-304. [CrossRef]

17. Imperato, M.; Kaario, O.; Sarjovaara, T.; Larmi, M. Influence of the in-cylinder gas density and fuel injection pressure on the combustion characteristics in a large-bore diesel engine. Int. J. Engine Res. 2016, 17, 525-533. [CrossRef]

18. Li, M.; Zhang, Q.; Li, G.; Shao, S. Experimental investigation on performance and heat release analysis of a pilot ignited direct injection natural gas engine. Energy 2015, 90, 1251-1260. [CrossRef]

19. Jeon, J.; Park, S. Effect of injection pressure on soot formation/oxidation characteristics using a two-color photometric method in a compression-ignition engine fueled with biodiesel blend (B20). Appl. Therm. Eng. 2018, 131, 284-294. [CrossRef]

20. Zamboni, G.; Moggia, S.; Capobianco, M. Hybrid EGR and turbocharging systems control for low $\mathrm{NO}_{X}$ and fuel consumption in an automotive diesel engine. Appl. Energy 2016, 165, 839-848. [CrossRef]

21. Zamboni, G.; Moggia, S.; Capobianco, M. Effects of a dual-loop EGR system and VNT control on the operating parameters of an automotive diesel engine. Energies 2017, 10, 47. [CrossRef]

22. Asad, U.; Zheng, M. Exhaust gas recirculation for advanced diesel combustion cycles. Appl. Energy 2014, 123, 242-252. [CrossRef]

23. Park, Y.; Bae, C. Experimental study on the effects of high/low pressure EGR proportion in a passenger car diesel engine. Appl. Energy 2014, 133, 308-316. [CrossRef]

24. Asad, U.; Tjong, J.; Zheng, M. Exhaust gas recirculation-Zero dimensional modelling and characterization for transient diesel combustion control. Energy Convers. Manag. 2014, 86, 309-324. [CrossRef]

25. Hsu, B.D. Practical Diesel-Engine Combustion Analysis; SAE International: Warrendale, PA, USA, 2002; ISBN 0-7680-0914-6.

26. Heywood, J.B. Internal Combustion Engine Fundamentals; Mc Graw-Hill: New York, NY, USA, 1988; ISBN 0-07-028637-X.

27. Hohenberg, J.F. Advanced approaches for heat transfer calculations. SAE Int. 1979. [CrossRef]

28. Benson, R.S.; Whitehouse, N.D. Internal Combustion Engines; Pergamon Press: London, UK, 1979; ISBN 978-0080227177.

29. Badami, M.; Mallamo, F.; Millo, F.; Rossi, E.E. Influence of multiple injection strategies on emissions, combustion noise and bsfc of a DI Common Rail Diesel engine. SAE Int. 2002. [CrossRef]

30. Torregrosa, A.J.; Broatch, A.; Martin, J.; Monelletta, L. Combustion noise level assessment in direct injection Diesel engines by means of in-cylinder pressure components. Meas. Sci. Technol. 2007, 18, 2131-2142. [CrossRef]

31. Badami, M.; Mallamo, F.; Millo, F.; Rossi, E.E. Experimental investigation on the effect of multiple injection strategies on emissions, noise and brake specific fuel consumption of an automotive direct injection common-rail diesel engine. Int. J. Engine Res. 2003, 4, 299-314. [CrossRef] 
32. Asad, U.; Zheng, M. Real-time heat release analysis for model-based control of diesel combustion. SAE Int. 2008. [CrossRef]

33. Liu, J.; Zhu, G.; Fu, J.; Xu, Z.; Yao, J.; Zhan, Z. Quantitative study on in-cylinder combustion and heat release characteristic parameters of gasoline engine based on single variable sweeping tests. Appl. Therm. Eng. 2017, 117, 487-500. [CrossRef]

34. Chung, J.; Oh, S.; Min, K.; Sunwoo, M. Real-time combustion parameter estimation algorithm for light-duty diesel engines using in-cylinder pressure measurement. Appl. Therm. Eng. 2013, 60, 33-43. [CrossRef]

35. Thangaraja, J.; Kannan, C. Effect of exhaust gas recirculation on advanced diesel combustion and alternate fuels-A review. Appl. Energy 2016, 180, 169-184. [CrossRef]

36. Kook, S.; Bae, C.; Miles, P.C.; Choi, D.; Pickett, L.M. The Influence of Charge Dilution and Injection Timing on Low-Temperature Diesel Combustion and Emissions. SAE Int. 2005. [CrossRef]

37. Eastwood, P. Particulate Emissions from Vehicles; John Wiley \& Sons Ltd.: Chichester, UK, 2008; ISBN 978-0-470-72455-2.

38. Mei, D.; Yue, S.; Zhao, X.; Hielscher, K.; Baar, R. Effects of centre of heat release on combustion and emissions in a PCCI diesel engine fuelled by DMC-diesel blend. Appl. Therm. Eng. 2017, 114, 969-976. [CrossRef]

39. He, T.; Chen, Z.; Zhu, L.; Zhang, Q. The influence of alcohol additives and EGR on the combustion and emission characteristics of diesel engine under high-load condition. Appl. Therm. Eng. 2018, 140, 363-372. [CrossRef]

40. Selim, M.Y.E. Effect of exhaust gas recirculation on some combustion characteristics of dual fuel engine. Energy Convers. Manag. 2003, 44, 707-721. [CrossRef]

41. Bunce, M.; Snyder, D.; Adi, G.; Hall, C.; Koehler, J.; Davila, B.; Kumar, S.; Garimella, P.; Stanton, D.; Shaver, G.; et al. Optimization of soy-biodiesel combustion in a modern diesel engine. Fuel 2011, 90, 2560-2570. [CrossRef]

42. Torregrosa, A.J.; Broatch, A.; Plá, B.; Mónico, L.F. Impact of Fischer-Tropsch and biodiesel fuels on trade-offs between pollutant emissions and combustion noise in diesel engines. Biomass Bioenergy 2013, 52, $22-33$. [CrossRef]

43. Jung, I.; Jin, J.; Lee, D.; Lee, S.; Yang, S.; Min, K. Closed-Loop control method for monitoring and improving the diesel combustion noise. SAE Int. 2016. [CrossRef] 